\title{
QUESTIONING QUESTIONS IN PSYCHOTHERAPEUTIC PRACTICE: THE DIALOGICAL DYNAMICS OF CHANGE IN THERAPY THROUGH CLIENTS QUESTIONING THERAPISTS
}

\author{
Line Brink Worsøe \\ University of Southern Denmark \\ line.worsoe@sdu.dk
}

Thomas Wiben Jensen

University of Southern Denmark

twj@sdu.dk

\begin{abstract}
:
The focus of this study is a particular type of questioning in psychotherapy: The unusual, yet recurrent, phenomenon of clients asking questions or making requests to the therapist and the way this alters the dialogical dynamics and therapeutic alliance between the two. Thus, we investigate how these types of question-answer cycles challenge the balance of the dialogical system of therapy including the normally accepted asymmetrical power relation between therapist and client. The analysis is informed by an ecological perspective which views the dialogical collaboration of therapist and client as forming a distributed cognitive system. The study shows how disaffiliation to questioning cycles on one hand stress the dialogical system through changing the language game, yet on the other hand, also entertain a subtle form of cooperativeness. The questioning cycles inform the dyadic system of therapist and client so that precautions can be made in order to secure the therapeutic alliance. ${ }^{1 *}$
\end{abstract}

Keywords: Questioning, psychotherapy, interaction, dis-alignment, collaboration, therapeutic alliance, ecological and distributed cognition. 


\section{Introduction}

What happens to the dialogical system of therapy when the client unexpectedly asks questions and makes requests to the therapist instead of the other way around? This is the pivot question of this article. Investigating the phenomenon from an ecological perspective reveals that reversed question-response cycles change the condition for the dialogical system, as the phenomenon transform the institutional pattern of rights, responsibility, and obligations. This article focuses on the interactive and distributed dynamics of two cases of client questioning in the psychotherapeutic encounter.

Therapy is a collaborative practice (Bercelli et al 2013). As shown in recent studies on psychotherapy (therapeutic alliance (Ponsi 2000, Bartesaghi 2009ab, Cornellius-white et al 2018, Garcia and Di Paolo 2018), solution building (Froerer and Jordan 2013, Jordan et al 2013, Taylor and Simon 2014), and client resistance (Guilfoyle 2002, Ribeiro et al 2014, Muntigl et al 2017, Yao \& Ma, 2017), psychotherapeutic conversing practices concern a multifold endeavor of 'talking to' and 'talking about' the client. This dialogical endeavor is characterized by activities of questioning and telling which is entangled in an interactive field (Bucholtz et al 2015). Questioning plays a vital role in both the therapeutic inquiry phases and the elaboration phases of therapy. The practice of questioning is an intervening tool and methodological technique to guide the client in building his/her personal narratives and to help the therapist to get a better understanding of the narrative and the problematic behavior of the client (Bercelli et al 2013), yet as such it becomes a vital tool for conversational control, a way for the dialogical system to do asymmetry (Buttny, 1996; Bartesaghi, 2009a). Given that the client is the fulcrum of this type of activity, the primary responsibility of doing questioning lies on the therapist, in order to steer, control and qualify the therapy. This asymmetric pattern works as enabling conditions for therapy and thereby constitutes the therapeutic encounter as an institutional type of activity (Linell \& Luckmann 1991, Sidnell 2009, Bartesaghi 2009, Heritage and Clayman 2010). Given the focus of recent psychotherapeutic process research (PPR) (Mörtl and Gelo 2015, Smoliak and Strong, 2018), most studies on questioning in psychotherapy concern the questioning practice of the therapists alone: how it is treated as interventions; how the clients align or misalign in their response; and what it does to the therapeutic process (McGee 1999, Voutilainen et al 2011, Yao \& $\mathrm{Ma}, 2017)$. In this article, however, the focus is turned towards cases where the client poses questions or make question-like maneuvers directed at the therapist.

The framework for describing questions has traditionally been guided by and restricted to (the field of) pragmatics. Within a framework of pragmatics, the question as a phenomenon has been described as an illocutionary act that has a directive illocutionary point of attempting to get the addressee to supply information (Crystal 1985). Pragmatics has developed within structural linguistics, as a way to account for the contextual dependence of language, and the premise of doing so thus entails a structural perspective, even on context. To take a stance against structural linguistics, we take an ecological perspective on language, which entails that languaged coordinated behavior, 
however structural in appearance, is constituted through the complexities of contexts in which languaging happens. This fundamental shift of perspective encourages an investigation of how contextualized systemic behavior of languaging enables question-like properties of action. We therefore seek to answer following question: How can an ecological perspective contribute to the understanding and investigation of questioning as a phenomenal activity? The activity of questioning transcends many different types of situations. Situations that are institutionalized in one way or another, are, due to their constrained characteristics, a preferred setting for investigations of questions. Here we investigate one specific type of institutionalized interaction, namely the psychotherapeutic encounter. The psychotherapeutic encounter is characterized by a special practice of contextualized languaged co-activity of questioning and is thus a privileged site to study questioning as ecological activity. Questioning in psychotherapy is crucial part of the asymmetrical patterns, which characterize or are associated with this particular type of institutional activity as a practice (Forrester \& Reason, 2006; Bartesaghi, 2009a). Yet, within conversation analytic approaches, it has been pointed out how institutional activities carry out practices of everyday talk (Sacks, 1992), and thus the process of therapeutic questioning is informed by everyday practice of doing questioning together. As such, studying the activities of questioning in psychotherapy can tell us much about questioning in general, just as the asymmetries engendered can tell us about the dynamics of asymmetry in general (Bartesaghi, 2009b). The smooth way both the clients and the therapists orient to the questioning activity of the therapeutic practice in general, is associated with a mutual acceptance of the institutional order.

During our study of questioning in psychotherapy, however, we found interesting sequences in our data, in which an interactional clash questions the degree of mutuality. These particular examples involve clients' acts of questioning the moral obligation and responsibility of the therapist, and thus thereby question the institutional order. When the institutional obligations and responsibilities of the therapist is questioned this way, it questions the institutional relationship and potentially stresses the therapeutic alliance. Hence, we explore the client's question, which is questioning the institutional order of which the therapist's questioning is a constituting feature. We seek to do that by the following: what does this reverse questioning do to the ecology of therapeutic practice? In the words of Harvey Sacks (1992: 419), people no matter what happens, engage with every effort possible in "(...) finding only how it is that what is going on is usual". What do the therapist and the client do with respect to each other to restore the institutional order of their mutual engagement?

\section{Focus}

The focus of the current issue is 'questions in language, culture and cognition', including the meta-concept of 'questioning questions'. Accordingly, it seems appropriate to define and further explain what is meant by the social constructs of questions and questioning before clarifying how we approach this phenomenon here. Relying on pragmatic theory, asking is a speech act (Searle 
1969), and how the interactants are co-operating in sense-making is relying on anticipatory illocutionary aspects (Grice 1963, 1975). Contrary to for instance physical actions, a speech act is considered to be done through language alone. The value of a speech act is derived from the linguistic prerequisites and rules agreed upon within a particular speech community. Speech acts consist of a propositional (locutionary) content conditions and an illocutionary point together with preparatory and sincerity conditions. The illocutionary force is comprised by combining the illocutionary point of an utterance, with particular presuppositions and attitudes that must accompany that point, including the strength of the illocutionary point, preparatory conditions, propositional content conditions, mode of achievement, sincerity conditions, and strength of sincerity conditions (Crystal 1985). Hence, the illocutionary force of an utterance is its compiled expression, that is, the value it is ascribed in the particular situation by someone/somebody. ${ }^{2}$ The question functions by activating a presuppositional force, that an empty frame (the absence of information) relative to and induced by the question, can be (and ought to be) filled out and completed. As such, an illocutionary act that has a directive illocutionary point of attempting to get the addressee to supply information.

\section{Questioning in psychotherapy}

The aim of psychotherapy is 'healing' dysfunctional thoughts and behavior through talk (hence 'the talking cure', Peräkylä et al 2008). Ever since Freud's psychoanalysis, the analytical priority has been on the clients' telling and how the therapist facilitates these activities. The activity of questioning has served as an engine for the therapist to get patients and clients to tell their stories and share their life experiences and psychological states (Conte 2009): "The therapist actively engages in how the client's problems get told: what gets picked up on and made relevant for further discussion, and finally, what becomes the problems for therapy" (Buttny, 1996, p. 126). Thus, from an early start, the psychotherapeutic encounter has been acknowledged as an asymmetric practice circling around the patient but steered and controlled by the professional therapist. Studies have shown some of the powerful strategies put into use by therapists to substitute clients' accounts. These strategies are interactional moves in how the therapist does authority (Bartesaghi, 2009b; Pawelczyk, 2017). Thus, the therapist as doing being professional is not a neutral force in the psychotherapeutic interaction, though it is often treated that way (Smoliak \& Strong, 2018). The therapist is seen as a neutral means of the professional institution he/she represents (Bartesaghi, 2009a).

In the last decades different therapeutic methods has been developed all formed around the individual as a dialogical social responsive organism, (Alberdi et al 2015). The aim here is not to discuss the different theoretical models of 'sense, mind, and self' of different therapeutic approaches, and the features of various therapeutic approaches will not be described in detail in this article. We will point out, however, that regardless of the epistemic model underlying each type of therapy, the interactional framework, i.e. how the different knowledge claims are realized through verbal and non-verbal gestures, shows similarities in form (Lepper \& Mergenthaler, 2007, 2008; 
Peräkyla et al, 2008). In example, significant qua-declarative formulations often occurring in psychotherapy regardless of therapeutic method (McGee 1999), are playing a part in so-called interpretation cycles (Peräkylä et al 2011).

An organization or an institution is recurrently maintained, renewed, and transformed through the way in which its members coordinate social actions together and in respect of each other: "it is within these local sequences of talk, and only there, that these institutions are ultimately and accountably talked into being" (Heritage, 1984, p. 290). Specific sequential formats configure and constrain the opportunities to speak and to initiate actions as they are shaped by the institutional context but also reflexively construct it in a number of institutional interactions (Mondada, 2012). This happen with regards to different levels of organization of interaction (i.e. turn taking, sequence organization, openings and closings, etc.), particular designs of the above (i.e. wordings, topic management, etc.), and underlying expectations and anticipations present in the settings and incarnated by participants (BenoitBarné \& Cooren, 2010).Though based on dialogical encounters, the therapist enjoys relative authority over the client, through membership of the institution. The psychotherapeutic session is a category-bound activity characteristic of a standardized pair, therapist/client, relying on a series of rights and obligations, and distributing epistemic claims, of which questioning constitutes a typical cyclic co-activity. The cyclic co-activity of questioning is most often initiated by the therapist and addressed to the client, but can also be initiated by the client, depending on epistemics and their organization. In this way, the dynamic activity of questioning rest on a functional asymmetry of knowledge: For the clients to engage in therapy means they need help, which means accepting feeling helpless to a large degree while knowing less about how to be better. What should be noted here is that if psychotherapy is a category bound activity, the interactional dynamics is constrained by an asymmetric organization in the expectation of "talking with/talking to/ talking about the client" (Buchholtz, Spiekermann \& Käschele, 2015). Even if therapists engage through doing self-disclosure, it ought to be strategically directed towards the goal of guiding the client to take a reflective stance (Leudar, Antaki \& Barnes, 2008).

Since the development of micro-sociological ethnomethodology and the field of conversation analysis in the sixties and seventies (Sacks, Jefferson \& Schegloff 1974), the dominant view on questions is, briefly put, that they acquire meaning in-and-through how they are treated in the flow of conversation. This makes questioning in psychotherapy a complex matter as it is a way of controlling the conversation but at the same time is fully depending on the client's interpretation and complying. The encounter of therapist and client is seen as dialogical, though still governed by institutional norms, which get expressed through asymmetric patterns of behavior (Heritage \& Clayman 2010). In the therapeutic encounter, questioning is considered a methodological tool for the therapist to intervene, to guide the patient and to control the therapeutic process (Adams, 1997; McGee et al, 2005; Bartesaghi, 2009a). They are a way for the practitioner to display understanding of the client's situation, to narrow down the topics of enquiry, and thus at best to perform and unfold the therapeutic project by gentle steering without losing 
the client underway. The success of questioning as interventions depends on the fine-tuning between therapist and client, that is, how well the therapist relate to the client as a unique person and as a 'client', and how well the client relates to the therapist as a person and as an authority, as well as how both engage in cooperative behavior, which incarnates therapy as an institutional system with certain expectations, and patterns of rights and obligations. It is a delicate navigation between conversational control while involving and encouraging the agency of the client (Buttny, 1996).

In this article, we look at the articulation between dialogical and interactional order and institutional order with respect to questioning practice in psychotherapy. Questioning practice as a form of, or a part of, therapeutic intervention (Adams, 1997), happens to go on unnoticed, in that it is constitutive of the psychotherapeutic institution. Through our investigation of the situated practices and interactional formats regarding questioning practice, we came upon questioning sequences, which seemed to disturb the institutional order rather than support it. The sequences showed similarities in how a practice of questioning all of a sudden was initiated by the client directing dialogical and moral obligations on the therapist rather than the other way around. In this way, these questioning cycles seem to concern a negotiation of agency, which was characterized by a significant change of the dialogical dynamics. This change in dynamics stresses the ecology of therapy as a coordinated endeavor of therapist and client. In our data, the formats and design of the questioning practice is constrained by the inherent asymmetry of knowledge with regards to the therapist as professional practitioners of therapy. In this way, questioning rights and obligation through initiating these questioning cycles, the clients do not only question the dialogical authority of the therapists, but may question the conditions of professional practice, and thus the very project of therapy. Furthermore, as will be shown in the following, questioning is a matter of coordinated behavior, which is not relying on verbal language alone.

\section{The ecological contribution}

Traditional pragmatic approaches have contributed significantly to our understanding of the phenomenon of 'questions' within the workings of semiotic language-based systems. However, from an ecological perspective, it is necessary to include the environment to a larger degree in order to investigate how humans exploit different sign systems embedded in the environment to organize their sense making activities (Goodwin 2013, Jensen \& Cuffari 2014). Cognition in example, from an ecological perspective, is seen, not as an inner mental ability, but as an active doing in an environment (Menary 2010). The focus of an ecological approach is on the profoundly relational character of the interaction between an organism/agent and its surrounding environment. Relations in this sense are not just a matter of configuration but has an ontological character as defining the status of the phenomenon under scrutiny. Things and phenomena are nothing in themselves; rather, they emerge as what they are in and through the relations, they are part of: Their relations are their "conditions of existence" (Hackel 1866, quoted from Eliason 2015: 80). In this way, an ecological perspective implies the study of relations. That is, 
how different (human) eco-systems function as differentiated, interdependent components of a larger whole that can adapt to changing circumstances. Following this, the study is informed by $4 \mathrm{E}$ cognition (Menary 2010), and the concept of double dialogicality (Linell 2009), where the therapeutic encounter does not only represent a distributed cognitive system of (doing) psychotherapy, but also forms a unique dialogical system (cf. Steffensen 2013) embedded in the ecological niche of psychotherapy. Doing questioning in psychotherapy is, from an ecological perspective, a highly heterogeneous and semiotically laminated co-action. It implies reciprocity and constitutes cooperative patterns of action cycles recurring over time. Doing questioning in psychotherapy rest on cognitive agents to recruit contextual resources from distributed social systems, which enables conditional changes of the situation. Such a perspective relies on a view on cognition as a skull-and-body transcending activity that emerges from the relation between an agent and the environment. The basic argument is that even though cognition is clearly dependent on neural activation in the brain, it cannot be thoroughly understood as just an internal process. Instead, cognition "is something we do: we enact it, with the world's help, in our dynamic living activities. It is not something that happens inside us" (Noë 2009: 64). In this sense cognition is not (an internal) precondition for action; it is not (just) an inner mental architecture that defines the route by which we are able to navigate in the world. Rather cognition is part of the navigation itself. In other words, we don't have or possess cognition (or cognitive abilities), instead we do cognition in our active and explorative sense-making (Linell 2009, Steffensen 2013). In this way cognition is re-conceptualized as part of an organism-environmentsystem (Järvilehto 2009, Steffensen 2013). In relation to the present study, human bodies are situated within a consequential setting involving other human beings. This means that in order to investigate how multiple humans/ participants negotiate understandings and build relevant action in concert with each other one must also consider the inter-bodily dynamics. Like in bio-ecological niche construction, social cognitive organization in the psychotherapeutic encounter, creates a certain set of conditions that change the selective landscape, e.g. affords particular ways of relating to the environment rather than others (Colombetti \& Krueger 2015: 1-2).

\section{Dialogical systems, social systems and "the third party" of a dialogue}

A general framework guiding this study is dialogism (Linell 2009), which deals with processes of human meaning-making in and through language, thinking, and activities. As a meta-framework dialogism covers epistemological assumptions about human actions, semiosis, cognition and communication. A core assumption is that our being in the world is socially guided, which means, it is interdependent with the existence of others. Since our perceptual systems are instrumental in sense-making, these are also part of these dialogical properties of human beings. Linell refers to this property of the subject matter of the human, as 'dialogicality' (ibid).

Dialogicality is a capacity to conceive, create and communicate in terms of otherness. This capacity is multifaceted, multivoiced and polyphasic in 
nature and embedded in history and culture. This means that dialogicality is concerned with more than the concrete encounter of individuals (e.g. the ego-alter, Markova 2003). Our first order activity, the dynamics of real time behavioral events that are co-constructed by co-acting agents (languaging, doing, remembering, conversing) is inevitably linked to historical, cultural and biographical conditions of a second-order, which permeates the hereand-now with situation transcendent dimensions (Thibault 2011). Therefore, the essential capacity of humans is a 'double dialogicality' (Linell 2009). Any human sense-making activity relies on a simultaneous relation between the local and multiple non-localities, therein being able to act in accordance with a population-level perspective (Steffensen \& Harvey 2018).

The complexity of double dialogicality might be more tangible when considering a distinction between the concrete dialogical system and a more abstract social system (Steffensen 2012). ${ }^{3}$ When engaging in conversation, we relate ourselves and others to various temporal and spatial dimensions: the situated interaction - the localized exchange and co-constructing of sense and meaning - and a situation-transcending practice - which is constituted by socio-cultural and historical resources, presuppositions, prejudices, or pre-defined characteristics of situations as particular communicative activity types (cf. Linell 2009). The situation-transcending practices emerge and are sustained with reference to a heterogeneity of temporal and spatial dimensions, and thus comprise what we here refer to as a 'social system. Social systems are second order constructed organizational frames formed by patterns and sets of norms over larger timescales, which stands in relation to the situated first order activity, which is real-time, contextually determined creative process of investing behavior in the dialogical system (Thibault 2011).

The distinction between first- and second order is used to designate how second-order cultural constructs arise out of first-order activity, rather than the other way around (Love 2007). It is easy to understand in relation to language, that first and second person always speak in the language of a third person: throughout our lives, we borrow meanings and expression from (languaged) activities in the world around us. "The world in language is half someone else's. It becomes 'one's own' only when the speaker populates it with his own intentions, his own accent, when he appropriates the world, adapting it to his own semantic and expressive intention" (Bakhtin 1981). Furthermore, even when the encounter is only between two individuals, like a psychotherapist and a client, there is always at least one third-party present (Linell 2009, Bang \& Døør 2007). The third party of a dialogical system might either be a specific 'third', a particular individual or community of individuals, or it might be an abstract generalized 'third' party, norms and preferences of abstract social systems, who in one way or another are given a voice through the actions of the participants (Linell 2009:100). It can be conceptualized as an 'observer' or an 'observed'. As an example, the concept of institutions, is understood as an abstract but often highly specialized or formalized version of social system, yet it is realized in what the therapist and the client do in respect to each other. The implementation of third parties covers a wide range of norm-orientating practices in the here and now, some of which happen through verbalization 
and others through other bodily co-actions. Sometimes they are scrutinized in the dialogical system, more often they are not, and whether or not is in itself a practice. This 'incarnation' of people not present and practices not questioned serves a referencing function between the dialogical system and various social systems, of which the institution of psychotherapy is just one among many. The synchronic activities of the agents are informed and qualified by the fact that institutions, corporations or communities frame a dialogue and the participating persons define and are defined by their position to the respective organization (Bang \& Døør 2007: 60).

\section{Semiotic resourcing}

In identifying how different social systems become enabling conditions for the dialogical system, we also need to consider which contextual and semiotic resources the agents of the dialogical system recruit as part of their coordinated practice. When humans relate to their environment through their coordinated behavior they tend to recruit, on the spot, whatever mix of problem-solving resources will yield an acceptable result with a minimum of effort (Clark 2008). The way semiotic resources relate to distant social system relies on the deictic capacity of their recruitment. The concept of deixis has been used to describe linguistic features that refer to some 'extra-textual' semantic and semiotic resources to inform their function in the communicative practice. Within pragmatics, it has been described how concepts of temporal, spatial and personal references is lexicalized and grammaticalized in (most) languages (Levinson 1983, Comrie 1996). In example, most linguists agree that tense "is a deictic category whose primary function is to relate the time of an event predicated in an utterance or discourse to some other time" (Fleischman 1989: 184, Binnick 1991), and that the aspectual feature of a verb refers to 'the internal temporal contour', through which a situation is interpreted as perfective (completed), imperfective (not completed) or habitual (repeated), and so forth (Comrie [1985]1993). Words like 'me', 'him' denote a personal dimension; 'now', 'soon', 'last Tuesday' denote a temporal dimension; and 'here,' 'there, 'at the Johnson's' denote a spatial (but also a temporal) dimension. Following Bang and Døør (2007) this line of reasoning could be taken a step further. Apart from the deictic categories of persons, time and space, Bang and Døør broaden the scope of deixis to also include reference to 'things' and 'media' (object deixis), as well as different kinds of logics, modality and lexis (logos deixis). This last group of logos deixis comprises "the kind of relationships that exist between individualities or the kind of coherence between individualities or relations (i.e. relations of relations) that is a particular historical fact" (Bang \& Døør 1996, cited in Steffensen 2007: 21). This concerns that different kinds of logics

are related to different situations and different social systems. If the logics of one social system drawn upon in the dialogical system is different than the logics of another social system drawn upon in the same dialogical system, then logics are just as context sensitive as person reference, and then logic is a deictic phenomenon(ibid:). Furthermore, the modality ascribed to what is said in the situation regards the language-reality relation and is tied to the situated practice and is therefore also related to a deictic process. Following 
Lepper (2009), the dialogical management of distance between the speakers in the psychotherapeutic dialogue, happens through the dynamic of deixis, as speakers regulate the intensity of in example emotive communication, through use of 'proximity devices' (Lepper 2009:1081). Proximity devices comprise a particular use of deictic referencing in relation to the degree of proximity, with which the interlocutors adhere (emotionally) to the telling (both the doing the telling and the event or experience being told). ${ }^{4}$

Apart from wordings, other embodied phenomena can be ascribed a deictic function in the psychotherapeutic encounter. Gestures or different form for bodily gesticulation can be investigated in terms of how they are recruited and combined ('in a laminated manner', cf. Goodwin 2013) to contextualize the next moment, and what projections they make in their particular positions. Gestures can function as a foreshadowing for imminent action, and thereby facilitate the mutual anticipation of social acts. "Different modes of gesticulation (e.g. depicting, pointing, displaying an illocution) differentially direct and focus the attention of the participants and in this fashion also contribute to the structuring of the interaction." (Streeck, 2010: 224). The positioning, actions, and orientation of the body in the environment are crucial to how participants understand what is happening and build action together (Goodwin 2013). From an ecological perspective however, it is important to note that even though the action of a gesticulation is grounded in the body, the formation and emergence of the gesticulation is intimately linked to and constituted by the ecological environment of the interlocutors. Though speech and gesture are routinely coordinated, gesture neither emerges in the speaker's mind nor just in the process of speaking. Gestures originate in the tactile contact that mindful human bodies have with the physical world. "Hands are entangled in the world that they reach - touching objects, grasping tools, wielding instruments, managing matter" (LeBaron \& Streeck 2000: 120). Following an ecological stance, rather than ascribing wordings and language primacy in the investigation, it is the wide variety and lamination of semiotic resources recruited and exploited which guide our study.

\section{Analysis}

In the analysis, attention will be paid to the interplay between the dialogical system, which is the actual dialogical situation in which dialogical activities happen, and possible social systems, which are more abstract phenomena constituted by set of social norms, preferences and valued activity types, upon which the local dialogical system draws. Focus will be on the various semiotic resources that 'agents' tend to recruit on the spot in their doing of the activity, i.e. physical detectable actions (hand gestures, other types of embodiment, verbal speech, tone speech and silence). The aim is to understand the dialogical dynamics of the counter-questioning in the therapist-client encounter on the micro-level. This means to investigate how the interlocutors select from various possible semiotic resources in co-constructing a sense of the situation. In order to follow an ecological perspective, these steps also represent different degrees of contextualization and re-contextualization. At first the narrow exchange in which the questioning is embedded will be described 
with regards to how various semiotic resources are recruited and exploited in a laminated manner (Goodwin 2013). Secondly, the dynamics described will be analyzed further in relation to how the dialogical system is informed by distant abstract social system of various kinds (cf. double dialogicality, Linell 2009) in and through relating various kinds of 'third parties' to the dialogue (ibid:). Whether a possible third party is physically represented in terms of artefacts, individuals or contextual settings, or whether it is absent and thus only covertly represented, the analysis is guided to identify possible instantiation of the third part position and determine how these possible third parties interfere directly or indirectly in the communication (Bang and Døør 2007, p. 60, Cooren, 2010). This step involves a back and forward movement in the wider context of the questioning as it comprises how any action is enmeshed in potentially contextualizing semiotic resources referring to various timescales (Trasmundi \& Steffensen 2015). The individual agents, as we shall see, represent in different ways various social systems or different aspects of the same social system. Thus, their coordinated dialogical actions show how they emerge as social actors in a dialogical system, which again rely upon how they relate to various distributed social systems. ${ }^{5}$ The analysis will focus on the talk, gestures and actions, where embodiment will be investigated as a central component of the sense making actions action within situated human interaction. In the table below (fig. 1), the various steps of our analysis will be presented in short form, informed by our theoretical stance above.

\begin{tabular}{|c|c|c|c|c|}
\hline \multicolumn{5}{|l|}{ Micro-level } \\
\hline \multicolumn{3}{|l|}{ Body } & \multicolumn{2}{|l|}{ Language } \\
\hline $\begin{array}{l}\text { Gestures (hand) } \\
\text { Gesticulations (facial expressions) } \\
\text { Gesticulations (prosody) } \\
\text { Gesticulations (gaze) } \\
\text { Gesticulations (body posture) } \\
\text { Gesticulations (other body parts) } \\
\end{array}$ & \multicolumn{2}{|c|}{$\begin{array}{l}\text { Streeck, 2010, } 2011 \\
\text { Goodwin, 2013 } \\
\text { LeBaron \& Streeck, } 2000 \\
\text { Kendon, } 1995\end{array}$} & $\begin{array}{l}\text { Wordings (semantic potential) } \\
\text { Utterances (pragmatic action) }\end{array}$ & $\begin{array}{l}\text { Searle, } \\
\text { Sidnell, } 2009 \\
\text { Leech, } 1997\end{array}$ \\
\hline \multicolumn{5}{|l|}{ 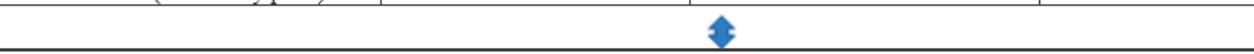 } \\
\hline \multicolumn{5}{|l|}{ The dialogical system } \\
\hline Gesticulations (deictic markers) & \multicolumn{2}{|c|}{$\begin{array}{l}\text { Streeck, } 2010 \\
\text { Goodwin, } 2013\end{array}$} & Wording (deictic markers) & $\begin{array}{l}\text { Bang \& Døør, } 2007 \\
\text { Steffensen, } 2012\end{array}$ \\
\hline \multicolumn{5}{|r|}{ ( } \\
\hline \multicolumn{5}{|l|}{ Abstract social systems } \\
\hline \multicolumn{5}{|l|}{ Third parties } \\
\hline \multicolumn{2}{|l|}{ Concrete: } & \multicolumn{2}{|l|}{ Abstract: } & \\
\hline \multicolumn{2}{|c|}{$\begin{array}{l}\text { Concrete, present actors } \\
\text { (who become relegated into the position of third persons) } \\
\text { Virtually present actors } \\
\text { (whose speech and thought are reported) } \\
\text { Absent concrete actors } \\
\text { (principals, remote audience) }\end{array}$} & \multicolumn{2}{|c|}{$\begin{array}{l}\text { Professions and institutions (as voices/values) } \\
\text { Society and cultural norms (as voices/values) } \\
\text { Concrete artefacts (tools, aids) }\end{array}$} & $\begin{array}{l}\text { Linell, } 2009 \\
\text { Bang \& Døør, } 2009\end{array}$ \\
\hline \multicolumn{5}{|c|}{ 산 } \\
\hline \multicolumn{5}{|l|}{ Ecological grounding } \\
\hline \multicolumn{2}{|l|}{ Topos } & \multicolumn{2}{|c|}{ Bio-social conditions } & Cultural-historical \\
\hline
\end{tabular}

Fig. 1 overview of objects of analysis 


\section{Data}

We look at specific cases, in which the client initiates question-response cycles instead of the therapist, which alter the conditions of the therapeutic dialogue. This analysis builds on a series of observations of authentic data from psychotherapy sessions. The study is guided by following pivotal questions: what do counter question-response cycles do to the therapeutic system, i.e. what happens to the therapeutic alliance and interactional dynamics of therapy when the client unexpectedly asks questions and makes requests to the therapist?

The therapists in our data all adhere to Mentalization Based Therapy (MBT). In MBT, a crucial goal is to enhance the client's ability to 'mentalize', i.e. to become aware of the intentions and motivations guiding own and other's actions (Bateman \& Fonagy 2010, 2012). A methodological principle for MBT is for the therapist to continuously stimulate a mentalizing process in the client (ibid; Alberdi et al. 2015). This is often done through therapist initiated questioning-response cycles directing the client towards practicing mentalizing or by explicit involving the client in the therapists' own observations on how they interpret the behavior of the client. Contributions like these, though therapist centered, show a questioning force, that is, a prompt for client reflection and acknowledgement. The therapeutic account of the account of what is being done "to stimulate a mentalizing process" are supposed to go on unmentioned. Yet interventions like these of course apply an inherent asymmetry of knowledge to the dialogical system, at least in that they are therapist ideated and driven. Due to our distributed approach in this article, we will not discuss the theory or knowledge claim underlying this epistemology further (see Jensen et al, forthcoming, for further discussion). This way, questioning practice can be tied to a notion of institutional authority as entrapment in discourse (Bartesaghi 2009ab).

The analysis is twofold: first the interactional level, then the dialogical and the systemic level. On the interactional level, the analysis concerns the coordinated actions of the agents, which include the wordings uttered together with prosodic gestures and bodily gesturing including movement and tension of body, hands, facial expression, and eye gaze. The analysis will concern case studies from two different dyads of client/therapist, in which the distribution of responsibility between therapist and client is altered through the client performing interactional authoritative behavior by questioning action. If we wish to understand how reversed questioning emerge and is being managed through interaction as well as how they end up having the kinds of consequence for the parties involved, we need to look closer at the inter-bodily and interactional details of the sequence. Thus, in the following analysis, we will investigate the emergence of the changes by focusing on how the unfolding of reversed question-response cycles are intertwined with three interrelated dimension 1) interactional dynamics, 2) unbalance in the dialogical system, 3) conflation of time-scales. 


\section{Analysis - part one}

In a therapy session, a female client (a single mother to a 2-3 years old daughter) brings a letter with her, directed by her former therapist as 'a letter of concern' to the municipality ${ }^{6}$, and asks whether the psychotherapist wants to read it. In the following part of the sequence the therapist's resistance emerges in a particular way. After some hesitation, the therapist responds to the request with another question, which engenders a very negative emotional reaction from the client's request. Looking in depth at the interactional trajectory, it is clear how the coordinated maneuvers of the two enable a shift of attention and thus change the condition for the dialogical dynamic.

When investigating something from an ecological perspective, the focus is systemic, i.e. the focus lies on what a countering question does for the therapeutic system. This part of the analysis will concern a question-response cycle (see fig. 2). This example is chosen because it represents a countering question initiated by the client, which turns out to re-organize the dialogical system and thus stress the therapeutic project through possibly harming the working alliance of therapist-client.

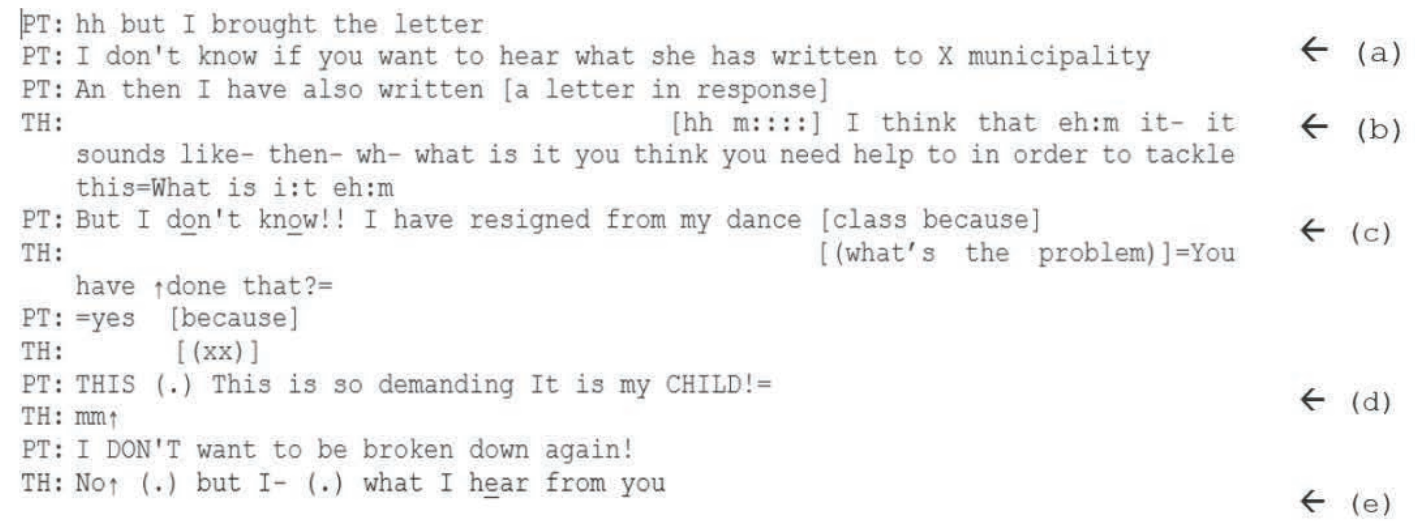

Fig. 2 transcript of question-response-cycles case 1

Participants: Therapist (TH), Client (PT)

In order to be able to capture every relevant semiotic feature of the questionresponse cycle, its various parts are separated and treated in depth below in relation to their function within the cycle: the question (invitation of response (a), ln. 1-3), the response ((b), ln.4-6), and the reaction to the response $((\mathrm{c}, \mathrm{d}, \mathrm{e}), \ln .7-14)$. The question in focus $(\ln .1-2)$ is formally designed as a que-declarative with a modus deictic marker. As such, though designed as an assertion, the illocutionary force of request for a response, makes it function as a question. To get an idea of what real forces are brought about, though, it is necessary to see what it does in example, how it enables and constrains certain types of coordinating actions in the dialogical system. 
* The question:

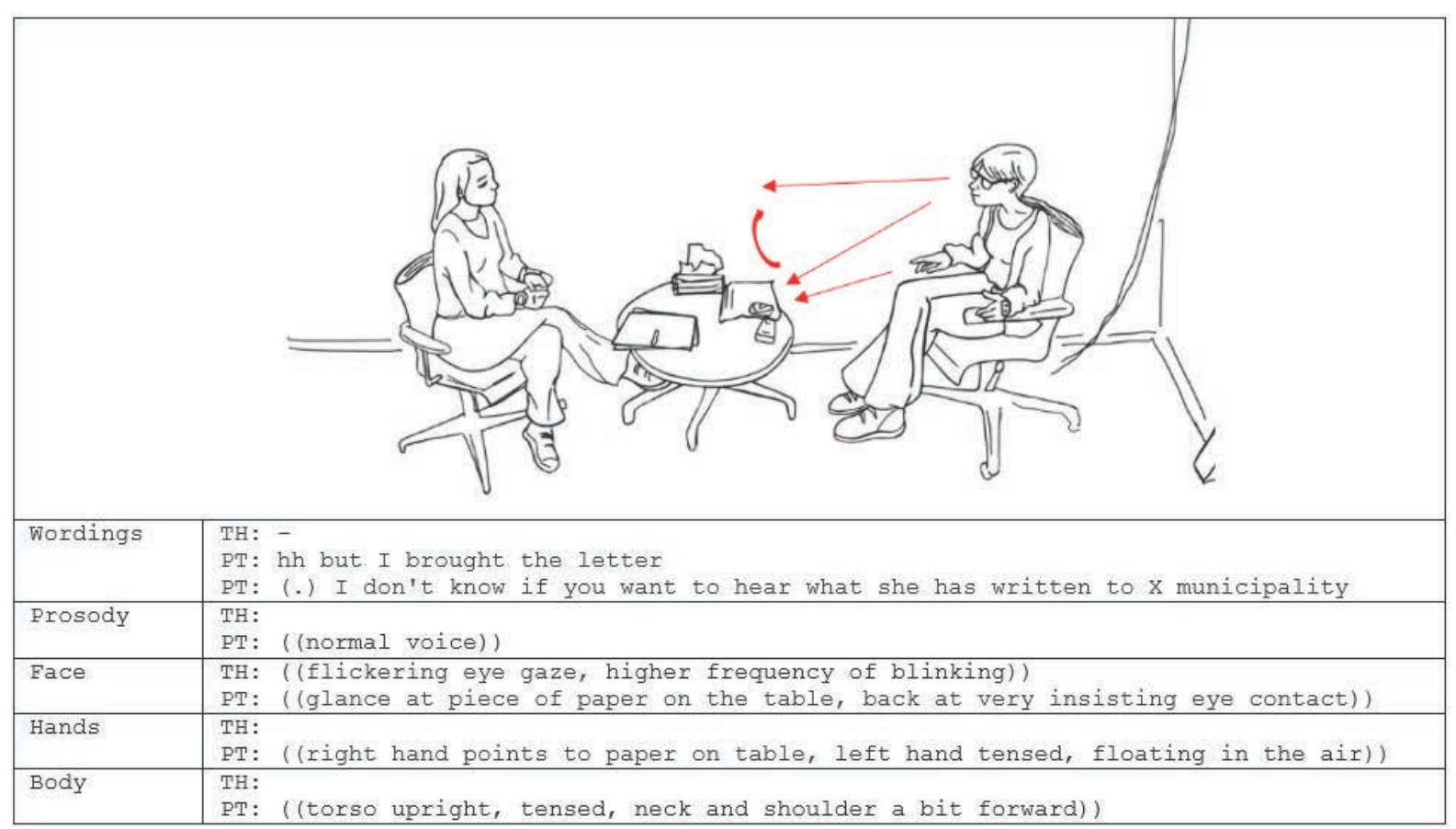

Fig. 3 the request $(\ln .1-2)$

The client relates a concrete but non-present third party, 'G', to the dialogue, a former therapist of the client, through the deictic marker 'she.' Though the dialogue up until now has been concerned with past experiences of the client and a former therapist $(G)$, this third party becomes physically represented by the artefact (the letter/the paper). This is done verbally and by deictic gesturing of both hand and eye glance. It seems to affect the attention of the therapist (she looks at the client), yet she does not react further.

The client has introduced the artefact (the letter), physically placed it on the table between the therapist and the client, and the therapist's attention is further drawn to the gesture as the client refer to the personal deictic 'you', the logos deictic 'if' and the modus deictic 'want' ("I don't know if you want to hear what she has written to X municipality". Here, another third party, is introduced through the lexical deictic of ' $\mathrm{X}$ municipality'. The municipality is an institution constituted by norms and responsibilities and thus is to be oriented to as an abstract social system. The two third parties are thus connected in and through the artefact. The tensed position of the client's body together with a direct insisting gaze supports the illocutionary force of questioning, in intensifying the responsibility of the therapist to react. The gaze of the therapist changes and the higher frequency of blinking might point to some sort of confusion or alertness. The conditional 'if' opens up an empty frame, in encouraging the deictic logos frame of 'if...then' (Bang \& Døør 2007). A conditional force in an 
utterance can be used to communicate what the prerequisites are for a state or an event becomes possible. The state or the event refers to something outside the utterance, either some physical conditions or agentive behavior. Following the cooperative principle of conversation (Grice 1963, 1975), what is needed in interpretation is anticipatory illocutions relying on interpersonal relations and contextualization. In daily life exchanges, the conditional 'if'-utterances can be ambiguous in that the interactant might diverge on interpreting logical implicature, which depending on the particularities of moral and valuerealizing engagement of agents (Brinkmann, 2005; Hodges). This makes a lot of 'if'-conditional speech acts heavily depending on contextual and situational aspects.

In her asking, the client seems to make use of the commonly known politeness strategy of hinting (Leech 1996). It is common to ask a question about an other's willingness or ability to perform an action $\mathrm{X}$ as a hint that you want them to do $\mathrm{X}$ - the first illocution does service for a second, unspoken one (ibid: 26). The hinting strategy exploits the maxim of relations (Grice 1963, 1975) in that in the context envisaged for an assertion about the other person's willingness or ability to do X will conceivable be relevant as a means of his/ her eventual performance of $\mathrm{X}$. From a pragmatic perspective therefore, the countering action done by this client involves a prediction or a kind of assertion about a future happening, and therefore indicating the client's confident belief that the future event will or could take place. Moreover, in having made vital prerequisites for $\mathrm{X}$ possible and making the therapist aware of it, the client seems to want the therapist to be aware that she wants her to do X.

\section{* The response}

The immediate response to the request falls in two phases (ln. 4-6 (b) in the above transcription): a withdrawal or retreat; and a counter question, as seen in the following (fig. 4 and fig. 5, respectively):

\begin{tabular}{|l|l|}
\hline Wordings & $\mathrm{TH}:$ hh m::: : \\
$\mathrm{PT}:$ And then I have also written [a letter in response]
\end{tabular}

Fig. 4 retreating $(\ln .4)$ 
The immediate reaction of the therapist, even as the request is uttered, is a prolonged minimal response. But while doing so, the therapist is turning first her face, her gaze, and then her body in the chair slowly to the right in a sweeping manner. The moving out of the responsive space both by the disconnected eye contact and physically by moving the body to face elsewhere than the client, expresses ambiguity ${ }^{7}$ This sudden activity, together with the hesitating cues (prolonged nasals), and frowning enables an interpretation of uncertainty or even discomfort (Heldner \& Edlund, 2010).

The therapist faces a great deal of pressure to answer the question within the parameters of the question. In her hesitating maneuvers, when answering, the therapist seems unclear on what terms and conditions, she ought to reply and the client continues her turn ("And then I have also written [a letter in response]"). By relating herself to the letter, the client further connects the dialogical system of therapist-client to the third party. This happens through the personal deictic 'I have written' in an activity like the one of the 'she has written' $(G)$.

\begin{tabular}{|l|l|}
\hline Wordings & TH: I think that eh:m it-it sounds like- then- wh- what is it you think you need help \\
to in order to tackle this=What is i:t eh:m [(what is the problem)] \\
PT:
\end{tabular}

Fig. 5 counter question (ln. 5-6)

After this period of ambiguity expressed in and through spontaneous bodily gestures, the response continues. The therapist, now turning back and facing the client, responds more thoroughly to the question with a countering question. This contribution exhibits four phases, which verbally show different dimensions of engagement: 1 ) the choice of verb 'I think' refer to an ideo-logic; to a personal belief (assumption rather than presumption), which stands in opposition to the epistemics of the situation, or knowledge of the profession. This way to claim insufficient knowledge becomes a strategic move for the therapist to level out possible conflicts; 2) The anaphoric reference of 'it' in the generic 'it sounds like' becomes blurred, which dissolves the liability of any agent, and the change of deictic mode realizes a interactional re-start evoking a certain degree of disfluency; 3) The change of agency in relation to 'you think' functions in opposition to the 'I think' earlier, which enables a shift in focus from generics to the dialogical system of the dyad. The 'it' in this phase is elaboratively indeterminate as object of 'what', and as before, there are several possible 'its' and thus several possible engagements of deixis. Yet though the therapist seems to appear to navigate blindly, due to hesitation cues and reformulation, she does more than just buying herself time to 'think 
a proper response through'. The dissolved liability of the generic 'it(s)' proves to be less face-threatening in the dialogical collaboration. This way it makes it safer for the therapist to delicately steering interaction towards concerning the client's obligation to the system, rather than the other way around. The alethic modality deictic function in 'need of help' is made to refer to an absence and a fulfilment (of something), of which different kinds of agencies are associated. These agencies refer to the norms of the therapeutic practice as a social system (responsibilities, asymmetrical rights and obligations), and hence this phase dialogically commits the other part to this system; 4) In the last phase, however, the perspective shifts to the interactive domain through a direct question 'what is the problem. The responsibility for answering the question in 4) lies on the client, as she has been pointed out to the accountable party in 3 ) 'what is it you need'. The problem however is not defined nor attached to an agent. The therapist's maneuver of omitting the ownership and character of the problem, expresses a gentle face-saving strategic behavior. The indeterminacy of the problem enables the client to be exempt from liability to a certain extent, yet the responsibility is redistributed by the therapist. The four phases are furthermore characterized by turn-internal pauses, false starts, re-starts, and prolonged syllables, which can be associated with increase of cognitive load. Together with the bodily gestured retreat mentioned, the prosodic features marking for hesitation, and answering question with another question, show a spontaneous orientation to something as potentially problematic in the dialogical system.

A few things could be at stake: First, the abstract social system of 'public authorities' also imply the (stately commissioned) psychotherapeutic treatment, which makes the responsibility of the therapist unclear. Secondly, by accepting the terms and conditions in answering the question, the therapist is obliged to evaluate the work of a colleague, since the author of 'the letter' ('G') is also a practicing therapist. This covertly implies a loyalty to another abstract social system, namely 'professional (therapeutic) practice'. There are thus several factors playing a part in this questioning-response cycle. It is of much bigger importance though, whether allying at all costs will contribute positively in the long term to the original task of the dialogical system - the therapeutic project.

\section{Change of interactional dynamics case 1}

* The reaction

In her questioning initiative above, the client relies on the therapist to do something. The therapist vaguely pushes the ball back, trying to get the client to account for what she thinks she needs, or account for what the problem is. Thereby, she is assigning the client agency and responsibility for something not clearly defined. As we shall see in the following, this maneuver makes the 
client break down in desperation and crying. The reaction of the client to the therapist's response is very abrupt and emotional. It falls in three phases ((c, d, e), ln 7-17): 1) a resignation phase ((c), ln. 7); 2) a desperation phase ((d), $\ln .12)$; and 3$)$ an aggression phase ((e), ln.17). The analysis will concern these phases one by one in the following (fig. 6 , fig. 7 and fig. 8).

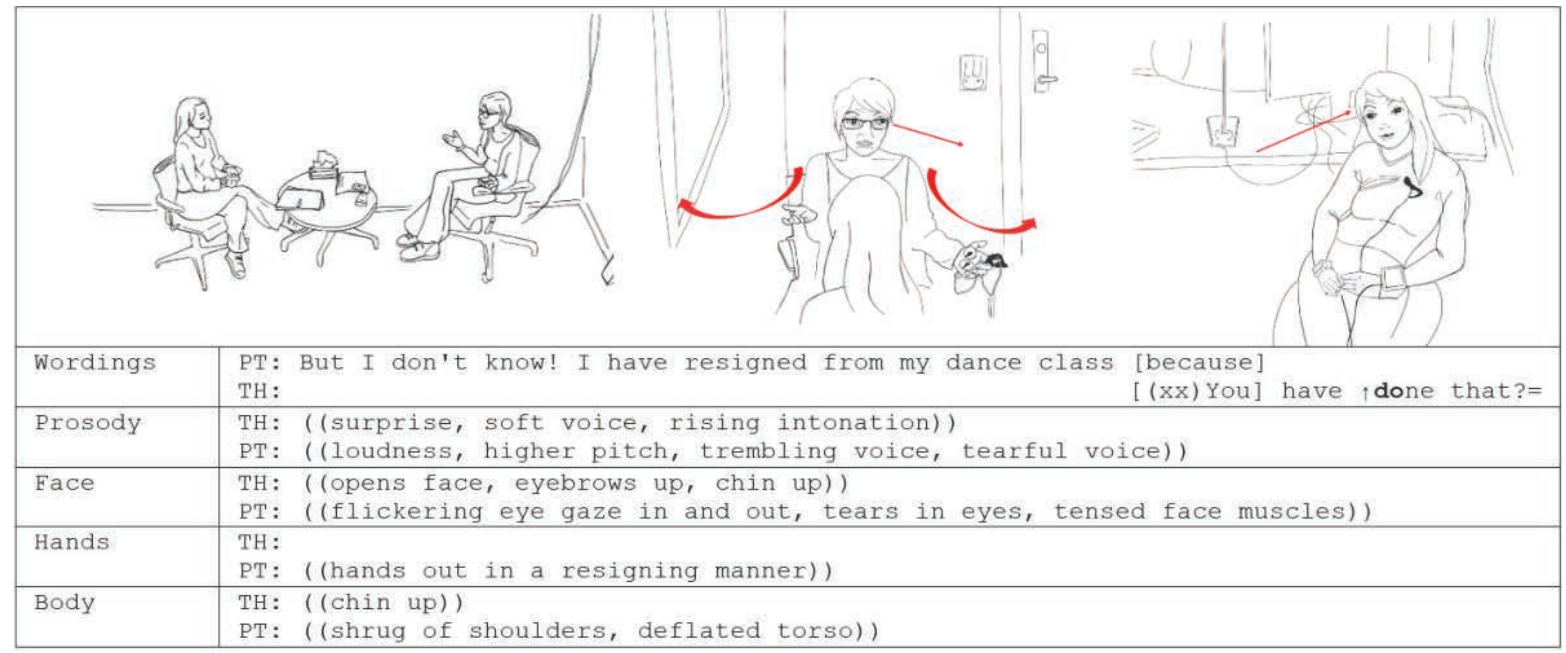

Fig. 6 Resignation (ln. 7)

The client promptly reacts to the therapist's response to the question. Her gaze starts to flicker, her eyes starts to be filled with tears. In shifting her eye gaze, she withdraws from the responsive space with the therapist, thereby enacting being alone. Her face reddens and her voice changes: she talks louder and in a higher pitch, and her voice starts trembling. Her body, which up until now has been tensed and held upright slight forward in the chair, deflates and she cast her arms to the sides in a resigned manner. The resigning gesture of the client together with the deflation of her torso signify 'defeat', or hopelessness, i.e. a loss of agency. Her attempt to drag the therapist in to be a co-active (allied) part of the conflict imposed by the letter has failed. The client has relied on the therapist to help. Yet based alone on the terms conducted in the dialogical system the therapist cannot provide the help the client thinks she needs.

The immediate bodily response of the therapist, however, involves lifting of her chin, which together with the risen eyebrows engenders an opening of the face towards the client, which stands in stark contrast to her previous withdrawal. The following rise of intonation in her verbal response (ln. 8-9) together with the opened face works to build a positive framing of the dialogical system. This positive framing works complementary to the very negative emotional cues expressed by the client. By coordinating her bodily and prosodic gestures to oppose the client's bodily and prosodic gestures, the therapist manages to steer the dialogical system away from being framed by the negative emotions. 


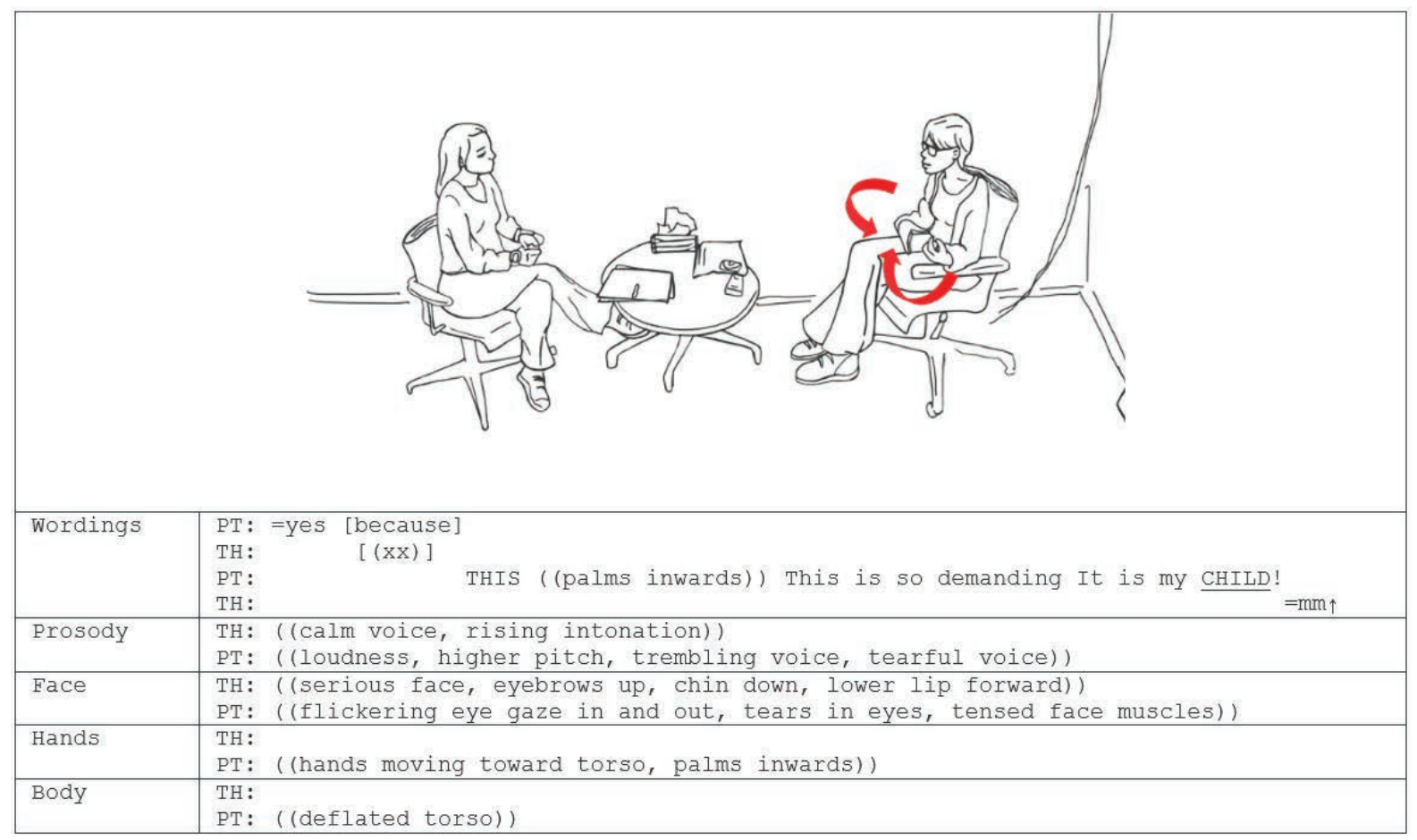

Fig. 7 desperation (ln. 12)

The client then makes an inward gesturing of the hands towards her abdomen, which metaphorically signals the proximity not only of the demands, but also of a concrete but non-present third party "my child" (her daughter, who has been introduced earlier in the session). This third party comes to represent the abstract social system of mother-child, through an orientation to the obligation of a close relationship therein. The gesture presentifies the system in the client's body, i.e. the proximity to the abdomen becomes an embodiment of the child. The therapist reacts accordingly by lowering her chin, which enables a firm gaze, which together with rounding of the lips adds seriousness and empathy to the situation.

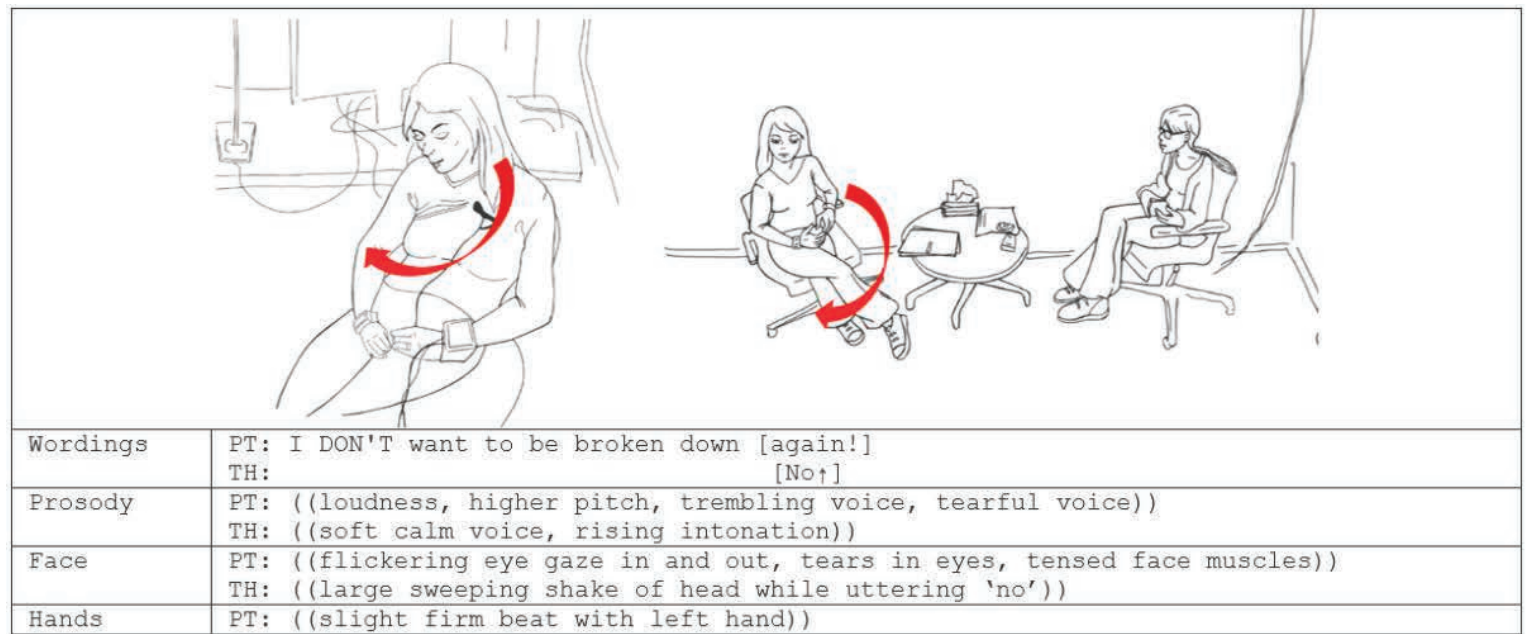

Fig. 8 aggression (ln. 14) 
The sudden firmness of the client's bodily gestures and wordings "I don't want to be broken down again!", is an attempt to regain agency. The modal deictic of the uttering imply not only the possibility of being broken down (a state, which is not preferred), but presupposes that certain events in the past were responsible for her breaking down. And now the letter (related to the third parties introduced) and the failed attempt to involve the therapist as an ally becomes threatening to the client. The dialogical system gets saturated with the need for defense, thereby implicating 'attack', and it needs to be explored further how this sense of 'attack' comes about.

This reaction tells us there is clearly a change of dynamics in the dialogical system. The client reacts very emotionally, first resigned, then desperate and then confrontative. The alliance between therapist and client up till now have been characterized by calm cooperative activity but is now altered due to the sudden change in the interactional dynamics. The system has undergone a transformation and is re-organized by the question and the following emotional reaction. The sudden strong negative reaction of the client bears signs of a clash of expectations. Either the negative emotions are reactions to not get help as she thought, or they are related the responsibilities and obligations she (all of a sudden) experience cause too much pressure and emotional stress. The emotional force with which the client suddenly reacts, is taking its toll on the dialogical system, yet, there has been no cues in the collaboration, which anticipated this serious change of dynamics prior to the questioning incident. The premises upon which the patient reacts so strongly lie not in the dialogical system alone, but is rather linked to another abstract social system, which at the time overrule the dialogical alliance with the therapist. Prior to this, there have been no cues to that the dialogical system poses pressure of this caliber on the client that could explain her reaction. This is also evident in the immediate reaction of the therapist, who acts as if caught off guard. The pressure may be an articulation of something else. The client reacts as to be negatively constrained by obligations she is subject to in relation to the system of $(G)$ and the municipality. This way the obligations of the social system is presentified in the reaction of the client. Different institutional orders are emerging through the changing dynamics of the sequence. There is a conflict between systems.

The immediate task of the dialogical system has transformed into repairing the alliance and restore the functional dynamics. The therapist's continuing of rising tone modulation (ln. 9, 13,15) construes (or retrains) a positive framing. This positive framing works complementarily (and thereby possibly counterproductively) to the very negative emotional cues of the client. The emotional force with which the client suddenly reacts is rooted in the constraints and obligations she is subject to in relation to other abstract social systems (in example, the system of $(\mathrm{G})$ and the municipality). By coordinating her bodily and prosodic gestures to oppose the client's ditto, the therapist manages to 
avoid the dialogical system to be hijacked by the negative emotions. Thus, after having bought herself some time to reflect and act, the therapist manages to change the impact of the letter by metaphorically introducing it as a spot on the client's perfectionism as can be seen in the aftermath example below (fig. 9):

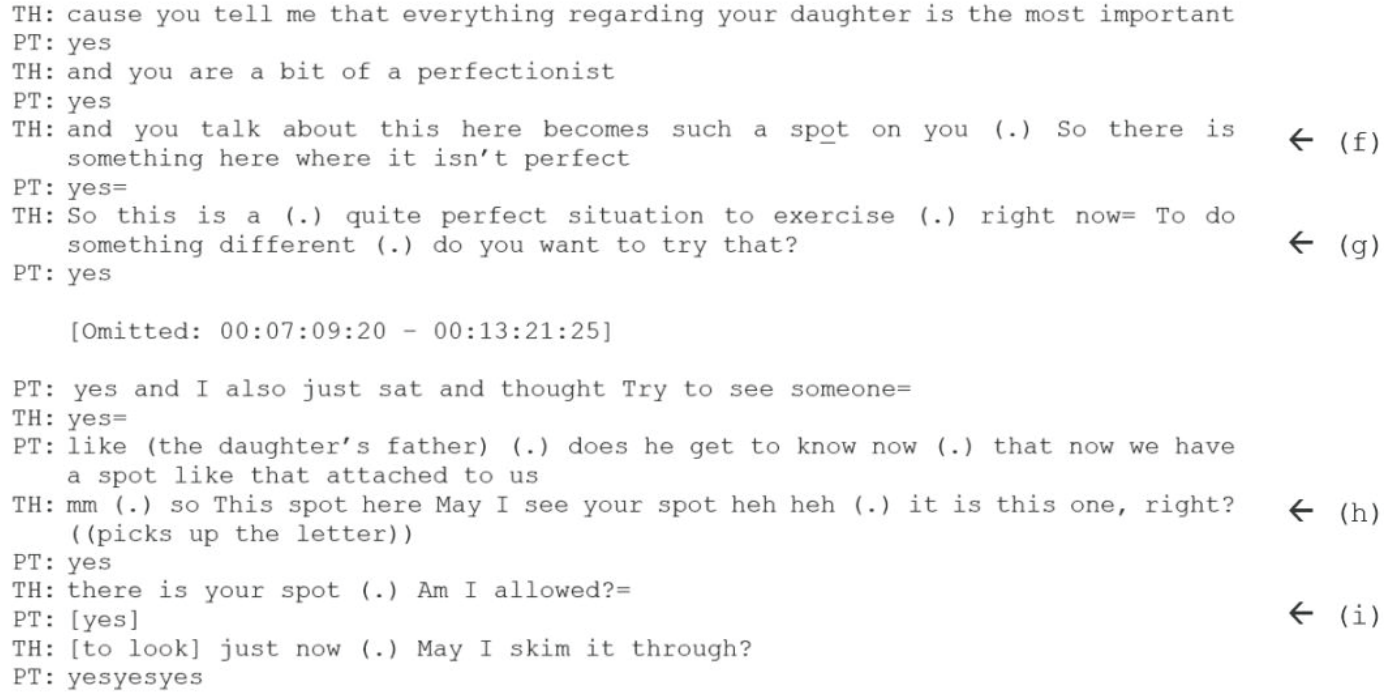

Fig. 9 the aftermath case 1

And as soon as 'the letter' has been reduced to 'a spot' ((f), ln.5), thereby establishing her condition for how to deal with it, the therapist takes initiative to skimming through it ((h, i), ln.18-24).

In sum, by introducing an artefact (the letter), which not only represent a conflict of the past (with the third party ' $G$ '), but also represents an authority, the dialogical system draws upon the very abstract social system of public authorities (the third party 'the municipality'). The client then introduces another third party (the child), which makes references to the abstract social system of 'family' or more narrowly 'mother-child'. The importance of this is underlined in the rights and obligations (the norms) of the public authorities to forcibly remove children from possible harming parents. The dialogical system becomes stressed by the conflict of these two social systems.

Summing up, the dialogical system is re-organized by the question in the following ways:

(1) First, the question changes the power relationship of the therapeutic practice. Therapy most often implies the practitioner to do the questioning and the client to do the answering/telling (McGee 1999). This distribution of tasks, rights and obligations constitutes the therapeutic practice in an institutionalized social system, where the practitioner is the authority. When posing the question, the client changes the asymmetric setting, and a transformation of agency occur. 
(2) Positioning oneself in a certain manner, implies the other part to be positioned or counter-positioned as well (Harré \& Langehove 1989). By adapting to a dominant figure in the dialogical system, the client is constraining the behavior of the therapist. The interactional force of the question alone is posing increased responsibility upon the therapist - she is obliged to answer in order to keep the interactional alliance stable.

(3) Finally, the invitation to read the letter of concern, becomes an invitation to engage in the conflict between the various abstract social systems, drawn upon by the client. Responding in a preferred manner, could enable the client to treat the therapist as an allied in the conflict.

\section{Analysis - Part two}

In a therapy session, a female client, after having raised fundamental doubts about her relationship with her partner, specifically asks the therapist not to take any notes on this particular issue (see fig. 10). After some hesitation, the therapist accommodates this unusual request. Like in the sample above, the coordinated maneuvers of the two enable a shift of attention and thus change the conditions for the interactional dynamics.

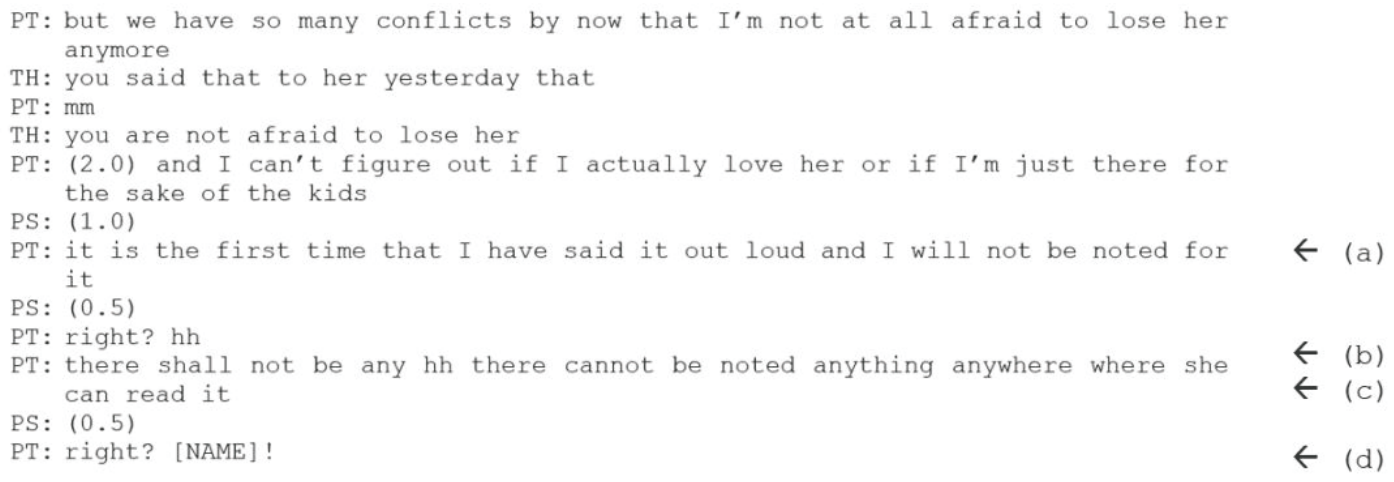

Fig. 10 transcript of question-response-cycles case 2

As in the previous example, this example is presented through the different parts being separated in relation to their function within the cycle: the question (invitation of response), the response, and the reaction to the response. The question in question here is a directive, disguised as an assertive with a modus deictic marker, and a tag-question marker. As such, though designed as an assertion, the illocutionary force of request for a response, makes it function as a question.

\section{${ }^{\star}$ The question}

In the above extract, we see how the client (PT) reveals serious doubts and raises fundamental questions about her relationship with her female partner 
(ln.1-8). In the following, this sudden revelation of the client is immediately followed by her unusually straightforward demand to the therapist (fig. 11 and fig. 12).

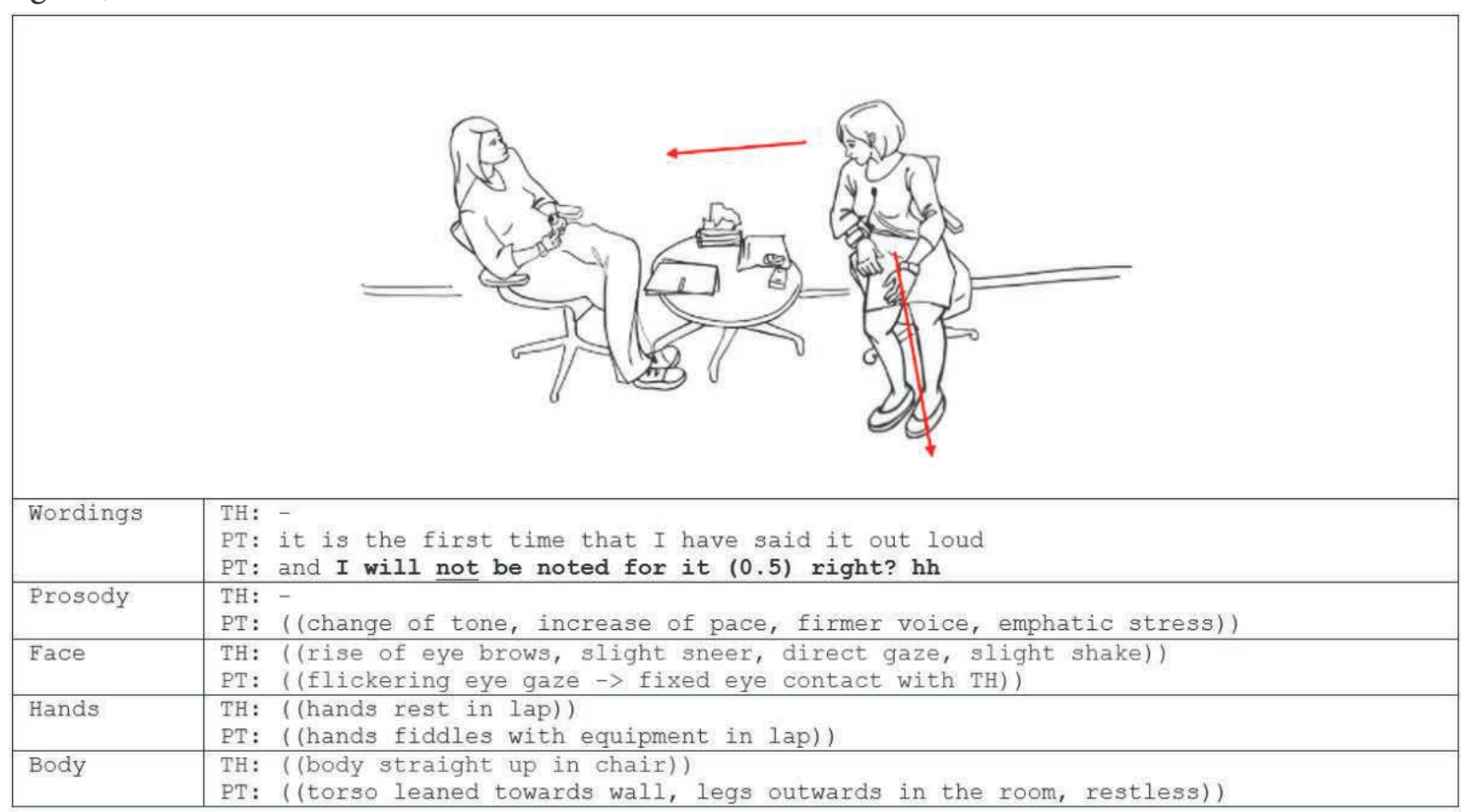

Fig. 11 question phase-I ((a, b), ln. 9-12)

The countering question falls in two phases: 'I will not be noted for it (0.5) right' ((a,b), ln.9-12) and 'there cannot be noted anything anywhere where she can read it (0.5) right? [NAME]! ((c,d), ln. 1316) In her design, the client begins her question as a directive imperative disguised as an assertion, and after a brief pause, the client adds a questioning tag, which mirrors the negative valence of the verb. Disguising directives or imperatives as assertions or even as weak questions (the tag sometimes treated as not more than a discursive marker) is a very common politeness strategy (Leeds 1996), yet the maneuver can function as the opposite due to the implicature of need for politeness design (Grice 1965). A directive or an imperative, would enable an even bigger threat to institutional norms of the dialogue and thus the authority of the therapist.

In the prior case example one, it was described how the presuppositional force of what otherwise looks like an assertion becomes 'asking someone to do something' (p. 21-22). In the same way, the current case example number two, though designed like a rather directive assertion, functions as encouraging someone to do (or in this case 'not to do') something. By this action, the client presupposes, that what she encourages the therapist 'not to do' is a possible future action, and that the therapist is able to comply. Of course, from the outside (and de-contextualized) it is up to 
the therapist, whether she will adhere to this obligation of 'not to do so', but the presuppositional force of the client's action is an act of authority, which as we see in the following, stresses the dialogical system. Yet giving the global institutional prerequisites, where the therapist is expected to be in a power relation to the client, doing authority, the strong engagement of the client in for the particular action not to be one, the incitement rather becomes a supplication or a plea from the client (Hansen and Heltoft 2011). From a pragmatic perspective therefore, the countering action done by this client involves a prediction or a kind of assertion about a future event $\mathrm{X}$ (the making a note by the therapist), and therefore indicating the client's confident belief that there is a possibility of the future event $\mathrm{X}$. It then follows, that by making the therapist aware of her resistance of $X$, the client wants to make the therapist aware that she wants her to do $\mathrm{Y}$ (which is non-X). In both cases, there is no determined agent of the action (noted vs. not noted). This is a politeness strategy, when conditioning other parties next action through directives. By not addressing the action to any specific agent, makes it less face threatening. Yet, in the second phase question, the therapist's name is attached, which makes her responsibility of commitment covert. In committing the therapist to respond (in a preferred manner), this exchange like the prior example, also concerns a dialogically reverse questioning-response cycle, which stresses the therapeutic alliance (Saffran et al 2011).

\section{Change of interactional dynamics case 2}

From the images fig. 11, it is equally apparent that the bodily dynamics between client and therapist at this stage is characterized by and outward expressive bodily style of the client - sitting with her side towards the therapist while leaning forward and looking directly, almost glaring, at her - whilst the therapist is put in a more passive position sitting still without gesturing while leaning back in her chair. There is a significant change in the tone of voice of the client, when moving from the disclosure to the demand (ln. 9-10). When she comes to the second phase of the question ((c, d), ln.13-16), she changes the posture of the upper body and the tone changes to very firm (see fig. 12). 


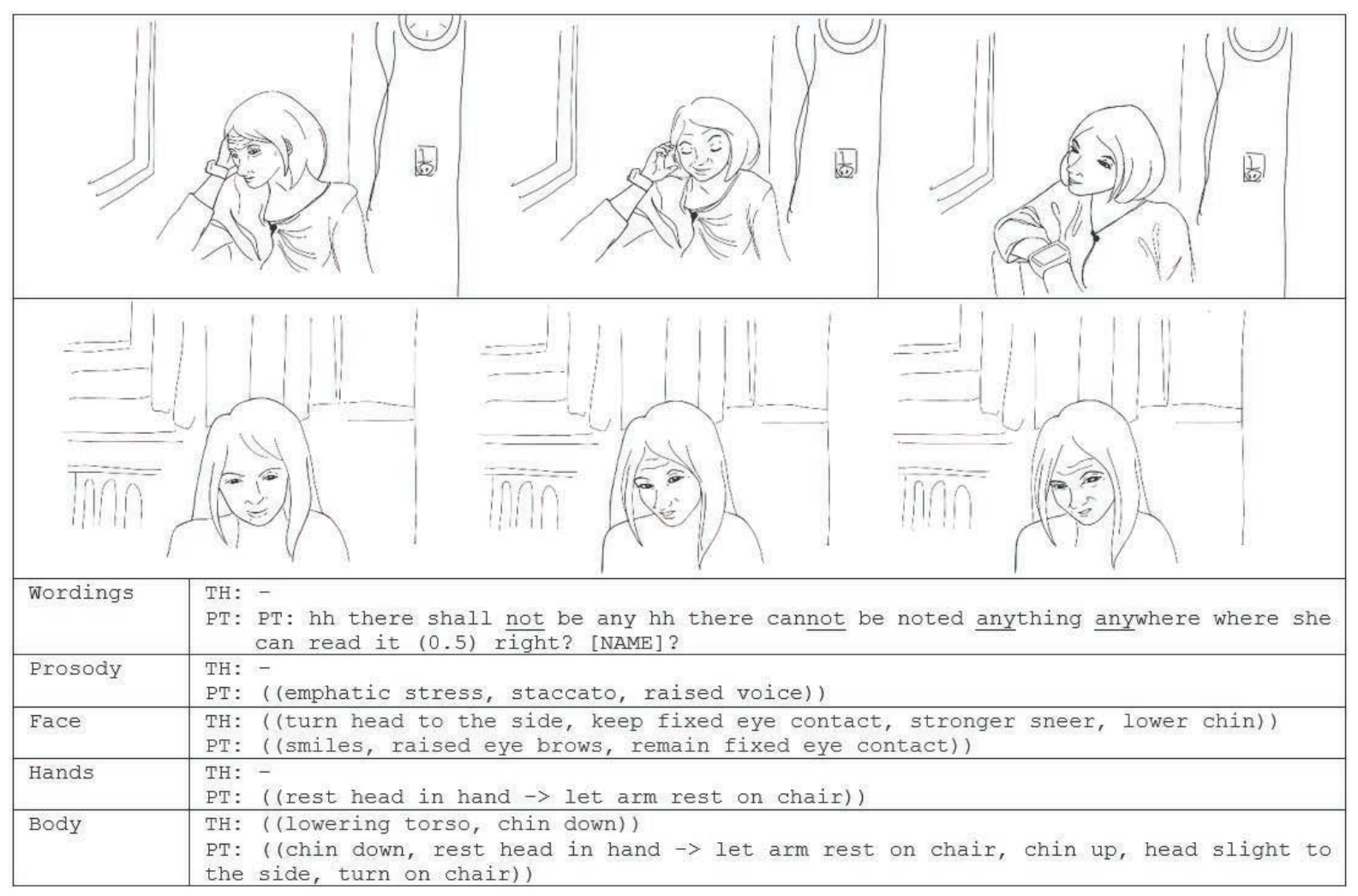

Fig. 12 question phase II ((c, d), ln. 13-16)

From the images it is apparent that the bodily dynamics between client and therapist at this stage are characterized by an outward expressive bodily style of the client - sitting with her side towards the therapist while leaning forward and looking directly, almost glaring, at her - whilst the therapist is put in a more passive position sitting still without gesturing while leaning back in her chair. The bodily behavior of the client seems to reinforce the impact and seriousness of the demand that the therapist has to deal with. In short, the therapist is put on the spot.

The two phases of the question furthermore introduce different dimensions of engagement. In 1) 'I will not be noted for it (0.5) right'(ln. 9-10), the future perfective aspect through the passive case of the verb, blurs the agent, while the dative referent of 'being noted' is the 'I'. The frame is ideological as it resembles the enabling prelude (the confession, ln. 9). In placing oneself in relation to an action of another person (though hidden), the agent of the action becomes a presupposition in relation to not only the dialogical system, but also the social system of therapy, in which the dialogical system relies. This happens through the modality deictic function in 'being possible' and the therapist being liable of the action 'making notes' due to her professional authority and rights. In the second phase, 2) 'there cannot be noted anything anywhere where she can read it (0.5) 
right? [NAME]! (ln. 13-16) the frame is shifted into relying on socio-logic deictic through the generic epistemics of the assertion. Whatever is to be noted does not refer to any agent nor object but has shifted into 'an absence' through the negative valence of the object ('not anything', 'not anywhere'). The spatial deictic function of 'there' is here also understood as a temporal deixis, as it refers to a possible future. But this time, the implementation of the third party 'she', relates the responsibilities of the dialogical system to be governed by the social system of 'emotional partnership' or 'marriage'. It is implied, that if anything is noted anywhere, there is an unavoidable possibility, that this becomes available for the partner to read. This stands in opposition to not only the confidentialities embedded in the dialogical alliance between therapist and client, but also the goal of the therapeutic project of becoming aware of and change dysfunctional thoughts, relations and behaviors. It thus creates stress between the systems.

As the presuppositional force of an assertion imposes a norm in the sociologics of the dialogical system, the client confronts the therapist directly by committing her to this new norm. After embedding the negative valence of the tag-question, the client even attaches the name of the therapist in the end of the request, thus demanding a confirming answer immediately. Such an extraordinary action from a client implicates a potential face threat (Goffman, 1967) for the therapist since it can easily be seen as a challenge of her professional authority. Thus, the roles between therapist and client seem to be switched around for a short while in the sense that now the client conditions a certain type of action or behavior on behalf of the therapist, not the other way around as would be the ordinary 'division of labor' in psychotherapeutic practice. The client takes on a dominating and controlling role in demanding that the therapist should not take notes on what has just been said.

* The response

As can be seen in the above, the therapist does not confront or challenge the client's behavior; rather, she sits still and seems to be awaiting the situation. However, if we look closer at the interactional and embodied details of the sequence it becomes apparent that the confronting behavior of the client in fact leads to a resistance strategy from the therapist. Looking closer at the trajectory of the client's demand, it is worth paying attention to the way it is structured encompassing two requests followed by small pauses of approximately 0.5 seconds (after "noted for it", and after "she can read it"). Both pauses potentially afford the therapist the opportunity to confirm or acknowledge the requests made by $\mathrm{P}$. However, none of these possible-completion-points (Sidnell 2009) are used to confirm or acknowledge the requests made by $\mathrm{P}$, not even by use of minimal responses, such as in breaths or head nods as is usually the case in conversation. Both pauses are followed by tag-question markers, which emphasize the need for response, but the therapist remain 
still. Then, the client adds the therapist's name, making it a direct personal request. Such a direct personal request that is almost impossible to ignore in this close interpersonal setting. It is thus noteworthy that the therapist does not react - neither verbally or bodily - to the two initial requests made by the client, but only responds after a third time when she gets "called out" by the client using her first name. On an interactional level, this suggests a resistance from the therapist towards the behavior and request of the client; however, this resistance is not displayed directly but is shown in-and-through the initial passive role of the therapist. However, in the following part of the sequence the therapist's resistance emerges in another way by altering the focus of the client and thus for a brief while the topic of conversation (fig. 13).

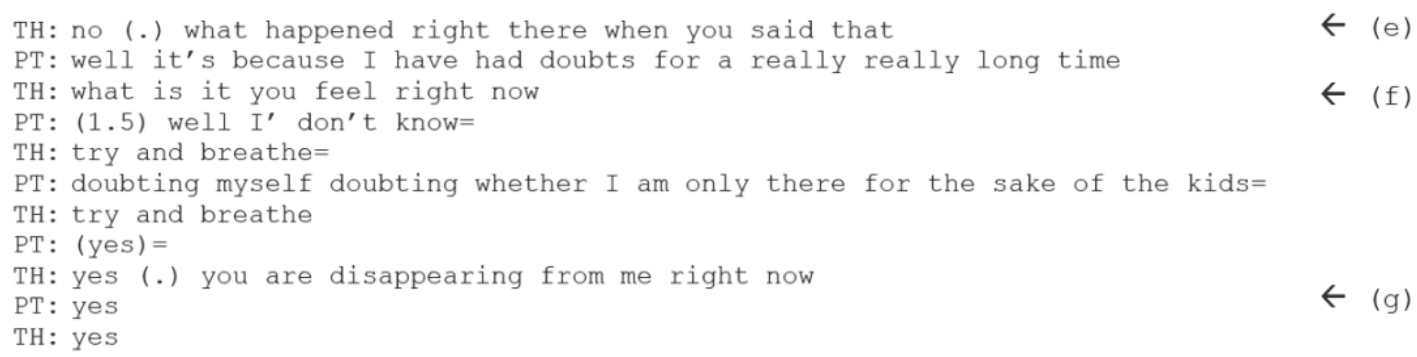

Fig. 13 response case 2

To start with, the therapist in fact delivers the desired response to the client's demand: The first word uttered by the therapist is a "no" as a response to the client's negatively framed request. As such, it follows the structure of a socalled preferred response $e^{8}$, in which a response abiding to the expectations of the request is delivered right away. However, even though the "no" of the therapist is delivered as an immediate response it is worth paying attention to how she contextualizes her response through three distinct semiotic features (see fig. 12) : facial expressions; bodily movement; and prosodic modulation. At the time, the client starts formulating her request with a firm almost glaring gaze at the therapist, the therapist starts to form a sneer surrounding a wary almost sceptic gaze with one raised eyebrow. The sneering and the lowering of the non-raised eyebrow become more conspicuous leading to a squint of the eye, as the client state a reformulation of the request (see fig. 12). Meanwhile the body of the therapist become lowered almost into a crouching movement. At the time the client states the reformulation of her request, now in a changed position, lifted chin and posing a firm challenging gaze and a grin, the therapist moves her head slight to the side. As the therapist spontaneous responds "no", she does it in a very low voice (almost impossible to hear on the recording), which could downgrade it to a mere discourse marker (aligning with the tag, but not affiliating with the question). These prosodic and bodily gestures inform the environment circumscribing the response. 
Immediately following her own minimal response, the therapist changes the topic of conversation in a subtle manner ((e), ln. 1). Rather than staying with the client's direct request, she asks the client in the first person to account for her immediate embodied and cognitive state: "what happened right there when you said that" ((e), ln.1) and, "what are you feeling right now" ((f), ln.3). It seems that the initial resistance of the therapist towards the requests made by the client has now turned into a more straightforward attempt to regain control over the therapeutic conversation. The therapist manages to change the focus and topic away from whether or not the therapist will comply to the above demands and instead steer the attention towards the feelings and psychological state of the client. Furthermore, the therapist initiates an attempt to control the client's embodied/psychological state by focusing twice on her breathing and verbally trying to keep her attention focused: "you are disappearing from me right now" ((g), ln. 9). Yet, by drawing the attention away from the client's demands, the therapist does more than just that. By focusing on the demands as disruptive and the client as somehow alienated ('disappearing'), the therapist ascribes the client a position of absence from the situation. This attribution subtly signals that what the client is doing is inadequate in relation to the dialogical alliance established and ought not to be taken as a valid contribution.

Clearly, this area of attention is more familiar terrain for the therapist (as it would be for any therapist) and it gains her the opportunity to

1. regain control over the conversation and re-establish a more conventional distribution of roles in which it is the therapist who asks the questions and the topic of conversation is the (behavior of the) client, not the therapist,

2. in continuation of this, to reclaim her professional authority as a therapist and thereby avoid another potentially face threatening situation, and finally;

3. simply to buy herself some time to figure out what to answer in a more definite manner.

These strategies are in fact available to anyone, but here they are conditioned by the functional asymmetry of the institutionalized system. When strategies like these are recruited by the therapist to enact this asymmetry, they take on the quality of therapeutic insights.

*The aftermath

The client complies hesitatingly with the therapist taking control and give in to the therapeutic alliance. Thus, after having bought herself some time to reflect and act, the therapist in the last part of the sequence finally delivers a more definite answer to the initial requests of the client (fig. 14, ln. 5-8): 


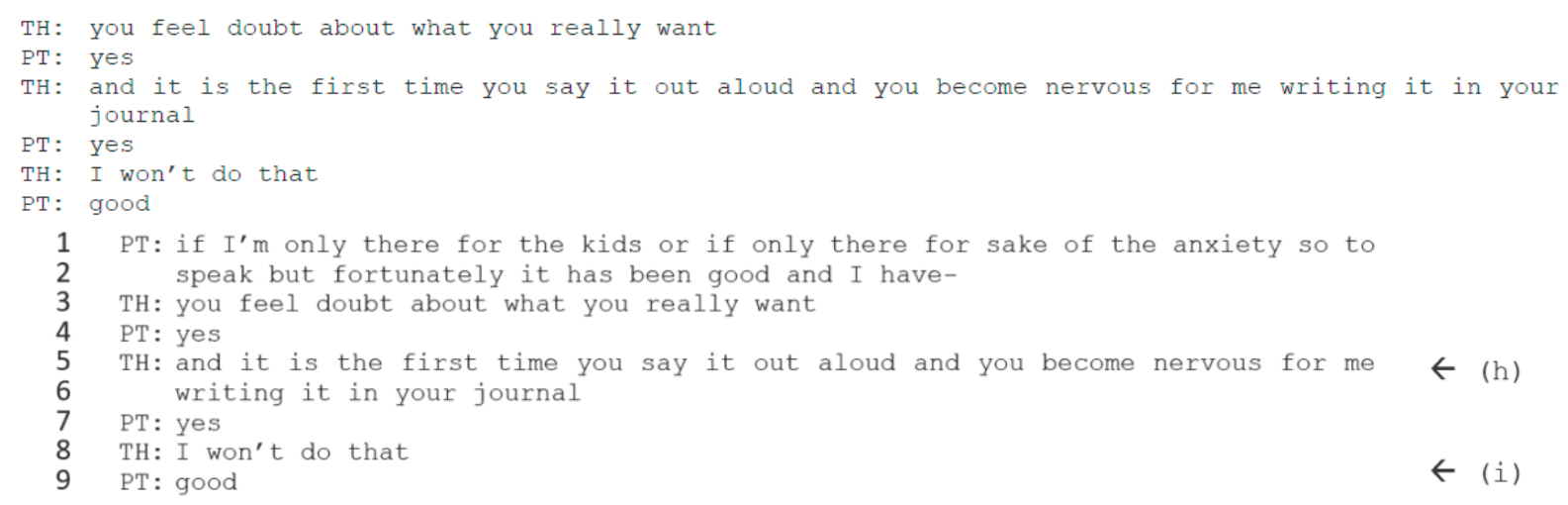

Fig. 14 the aftermath case 2

\section{Unbalance in the dialogical system}

From a more systemic point of view, one can add that the initial face threatening behavior of the client (in both of these examples) creates an unbalance in the dialogical system (Steffensen 2012) that needed to be adjusted before the desired action or answer (giving the client an answer to her request) can be delivered. The therapist needed to regain her position in the system as an active agent that does something for the client and no just reacts on the needs and behavior of the client.

Regarding the effect of the client's questioning the therapists on the therapeutic system, the point is that they cannot be treated or understood adequately separated from these dynamics; rather they should be regarded as embedded in the embodied and interactional environment from the very start. Thus, a focus on keeping the client's autonomy is deeply constrained by the dynamics of the situation in which the client demands autonomy on behalf on herself, but at the same time potentially threatens the autonomy of the therapist (in telling her what to do and not to do in relation to the therapy session). The point being that different needs for different types of autonomy must be balanced towards each other in situ during the course of the conversation which makes it indispensable to look at how stressing of the dialogical system emerges as part of an ongoing interaction.

All of these elements put the dynamics of the therapeutic project into perspective and highlight how difficult it is in real life situations to balance the different concerns. In the end both therapists deliver the desired response (read the letter, promise not to write it down). Even though the therapists subsequently have expressed some doubts and regrets about their decision, these were made under pressure as a consequence of an unexpected request during the fast flow of conversation. As stated by Trasmundi et al (forthcoming) it is often the case with real life professional practice, there is little time to reflect on how to deal with challenges of trust related to past experiences and dysfunctional behavioral patterns in the present situation sitting face to face with another human being . 


\section{Discussion and perspectives}

\subsection{The interrelated nature of timescales in therapy}

Therapy requires practitioners to create active constructive environments that promote, mobilize and value the role of the clients' ability to form complex thoughts and questions. Analyzing questioning events from an ecological perspective, it becomes clear that the conversations unfold on two different levels or dimensions: In both cases the client is 'doing telling of an event' but in doing so, she also re-enacts the event, by dis-aligning herself to the behavior of another (distant) agent (' $G$ ' in the first example and 'the partner' in the second example), which for both clients cause an emotionally vulnerable state to appear. The therapists on the other hand, try to hold on to the emotional stance of the client in the here and now. In this way, both examples addresses the question of how an event can involve different temporal dimension: The bio-mechanics of the bodies, which owes its capabilities to evolution and sociohistorical appropriation - the emic timescale, which of course is conditioned by both the lived life of the individual, but also the socio-cultural appropriation - the deontic timescale, which is informed by the double dialogicality of the two bodies in encounter.

Thus, the co-doing of therapy needs to be seen as embedded in different timescales. There is the timescale of the here-and-now in which the interaction takes place, and which is highly influenced by the inter-bodily dynamics of the situation. However, the dilemma of respecting the request of the client or adhere to it, is also to a very large degree constrained by the therapist knowledge of the client's previous pattern of behavior on a longer timescale. In example one, it is unclear whether the client will benefit in the long run, if the therapist engages in the conflict with her. Complying with the wish of the client might commit the therapist a pattern of dysfunctional behavior of the client. The therapist in example two knows that the client has severe difficulties in setting the limits in her relationship to her partner. On the one hand this makes it likely that the partner of the client may indeed read the notes from the session since she has been allowed to do so before. On the other hand, abiding to the wish of the client is to reinforce a pattern of violating behavior. The ambition of the therapist is to get the client to see alternative ways of acting in which it is ok to maintain your own perspective, for instance by writing it in the journal and thereby acknowledge the problems in the relationship and trying to deal with it in a more constructive manner without subordinating the perspective of the other. Thus, on a shorter timescale the therapist may do good to the client by not writing anything down, however, on a longer timescale it will likely prove the exact opposite. As in the first example, the therapist might do good on the shorter timescale, by unconditionally reading the letter, but on a longer timescale, the conditions for complying need to be specified with regards to the therapeutic project. Again, there is no straightforward way to foresee the consequences. 


\subsection{The ecology of pragmatics}

Taking an ecological perspective on pragmatics, descriptions based on traditional reference-predicate distinction in psycholinguistics (categorization-predication) cannot provide an adequate analysis of certain types of utterances that form a part of activities (Borchmann 2018). A basic pragmatic assumption is that performers of activities share the states of variations by means of utterances. Yet, how performers of activities attend to variations in the environment is not restricted to the utterance alone (ibid.). From a pragmatic point of view, then, an informative and accurate analysis of utterances that form a part of activities relies on two distinctions: a distinction between a convention-based regulation of attention through wordings and a convention-based specification of an affordance, and a distinction between sharing information and nesting information.

Identification of invariants in and of the environment, however, relies on the entire perceptual systems of humans engaging and relating in and to the world on various timescales. As we have seen in this study on psychotherapy, questioning-response-cycles afford different forms of agency and plays a role as a capacity for managing autonomies and coordinating dynamics of various dimensions. This points to the question of the conditions on which we determine the degree of conventionalization, when specification of the affordances of an activity or a situation is to be based on convention.

Following from this, pragmatics can be seen as a field which is concerned with the living in and through the ecology of languaging co-activity and co-cognizing. The understanding of a languaged activity such as question, we have argued, depends on an ecological perspective that opens up for considering questions as constituted in a larger question-response cycle. In our cases, the question-response cycle always involves a change in the system. As shown in the analysis, the dynamics between question-responsereaction cause the environment to change, thus altering the conditions for the distributed cognitive system. The main responsibility for sustaining the therapeutic system, due to the institutional norms of psychotherapy as a social system, is ascribed on the practitioner's part. Still, a single counter-question from the client makes a change in the conditions for flexible adaptive behavior of the system as a whole. Even more so, the change is difficult to anticipate and none of the participants can fully understand the possible consequences of this change.

To sum up, in the psychotherapeutic encounter, the dialogical system emerges through the sense-saturated coordinated interactivity of the therapist-client dyad. Given the double dialogicality of human beings, the dialogical dynamics of this system is defined by the nature of how the agents relate to and localize otherwise non-local aspects. This is indeed the case with psychotherapy. Not only is the dialogical system of therapist and client constrained by the abstract social system of therapy, which is represented both in practice, norms, and settings of the dyad, but also in the institutionalized 
features of these (interactional asymmetry, power-relations, goal-orientedness, obligations). An ecological perspective on therapeutic practice can contribute to a better understanding of the complexity of what kind of information is shared and how it is nested within different types of interrelated systems.

\section{Appendix A) Danish transcripts of excerpts}

Case 1

[00:02:14.17] P: øhm (.) og så siger hun så til mig at øhm (.) det fordi der var en gang da jeg var ude i xxx det cirka et år siden

[00:02:24.15] T: $\mathrm{mm}$

[00:02:25.14] P: øhm (.) og- og det var ikke godt for min stress jeg var ude i xxx i sådan et jobafklaring (.) og så s- (.) så øh var der en dag der opdagede jeg at- (.) jeg fik sindssyg meget energi og jeg tænkte bare (.) fuck det her det kører bare og (.) jeg kan bare køre i syvogtredive timer og (.) men alligevel så tænkte jeg bare der er et eller andet galt fordi sådan plejer jeg ikke og have det (.) altså det var som om at jeg var sådan helt øh høj eller hvad man siger

[00:02:50.07] P: [altså jeg] kunne bare det her (.) og så ringer jeg til min mor for og høre efter om hun vil hente [navn] (.) jeg kontakter min mentor (.) og jeg kontakter g[navn] fordi jeg tænkte der er et eller andet fuldstændig galt med mig fordi sådan her plejer jeg ikke og have det [00:02:50.07] T: [mm]

[00:03:05.07] T: så da du havde energi og overskud så ringede du efter dem [00:03:09.10] P: ja [00:03:09.25] T: til og tage over fordi du tænkte der var noget galt med dig [00:03:12.07] P: ja lige

[00:03:12.26] T: [okay] (.) fordi

[00:03:12.26] P: [nøjagtig]

[00:03:14.16] P: og [navn] hun sagde det var fordi at min stress var så høj så jeg havde svært ved og (.) komme ned og slappe af [00:03:20.03] T: mm [00:03:21.24] P: og så blev min praktik stoppet ude i xxx og jeg har aldrig haft den der episode siden (.) men den skriver hun også i hendes bekymringsbrev (.) efoaeri eller sådan noget efoani- eufoari eller sådan noget (.)

[00:03:33] men jeg har taget brevet med jeg ved ikke om du vil høre det hun har skrevet til xxx kommune

[00:03:38.28] T: mm

[00:03:39.26] P: og så har jeg også skrevet et brev tilbage

[00:03:43.10] T: jeg tænker mm det det lyder- altså- hv- hvad er det du tænker du har brug for hjælp til i forhold til og tackle det her hvad er det øhm [00:03:50.01] P: [jamen det ved jeg ikke jeg har sagt mit] danse kursus op [00:03:50.01] T: [hvad er problemet lige nu] [00:03:53.05] T: [nå det har] du 
[00:03:53.05] P: [fordi]

[00:03:54.03] P: [ja fordi] (.) at det her det fylder så meget det mit barn

[00:03:54.03] T: [simpelthen okay]

[00:03:57.23] T: mm

[00:03:58.26] P: og jeg vil ikke knækkes igen

[00:04:00.15] T: nej (.) men je- det jeg hører her

(Omitted: [00:04:00.15 - 00:06:55.09])

[00:06:55.09] T: og du er lidt perfektionistisk

[00:06:56.27] P: ja

[00:06:57.06] T: og du taler om at det her det bliver sådan en plet på dig (.) så der er noget her hvor at det ikke er perfekt

[00:07:02.06] P: ja

[00:07:03.03] T: så det er en (.) helt perfekt øvesituation (.) lige nu til at gøre noget andet (.) er du med på den

[00:07:09.07] P: ja

(Omitted: [00:07:09:20 - 00:13:21:25])

[00:13:21.25] P: ja og jeg sad også bare og tænkte prøv at se sådan en [00:13:24.12] T: ja

[00:13:25.17] P: som bo (.) får han nu af vide (.) at nu har vi sådan en plet der på os

[00:13:30.16] T: mm (.) så den her plet må jeg se din plet haha (.) det denne her ikke også

[00:13:34.19] P: ja

[00:13:35.01] T: der er din plet (.) må jeg have lov

[00:13:36.06] T: [og kigge] lige sådan (.) må jeg have lov og skimme det

[00:13:36.06] P: [ja]

[00:13:38.14] P: jajaja

Case 2

[00:28:14.25] P: og jeg kan ikke finde ud af om jeg egentlig elsker hende eller om jeg kun er der [00:28:17.19] P: for børnenes skyld

[00:28:20.24] P: det er første gang jeg har sagt højt og jeg vil ikke noteres for det (.) vel

[00:28:25.17] P: der skal ikke være noge- komme til at stå noget om nogen steder hvor der m- nogen kan læse det

[00:28:30.18] P: vel [navn]

[00:28:31.14] T: nej hvad skete der lige inden i dig da du sagde det der

[00:28:33.28] P: jamen det er fordi jeg har været i tvivl rigtig langt- i lang tid

[00:28:37.20] T: hvad er det lige du mærker lige nu [navn]

[00:28:43.26] P: jamen det ved jeg ikke

[00:28:44.20] T: prøv lige at trække vejret 
[00:28:45.08] P: tvivlen på mig selv tvivlen på om jeg kun er der

[00:28:49.16] P: på grund af børnene

[00:28:52.04] T: træ- træk lige vejret

[00:28:53.14] P: ja

[00:28:53:50] T: ja

[00:28:55.11] T: du forsvinder fra mig lige nu

[00:28:56.25] P: ja

[00:28:57.02] T: ja

[00:28:59.27] P: men det er fordi...

\section{Notes}

$1^{1^{*}}$ This work was supported by the Velux Foundation (Grant no. 10384). Further, the work was carried out by in a close collaboration with Brønderslev Psychiatric Hospital, Denmark. We thank all employees, clients, and psychotherapists at the outpatient clinic for anxiety and personality disorders at. Without their time and expertise, this research would not have been possible

2 That is, the illocutionary force refers to 'speaker's intentions' whereas how the speech act is treated by the hearer is implied in the perlocutionary force (Searle 1969). The pragmatic framework of speech acts functions through giving primacy to language as a communicational system. However, according to the view presented in this article the dynamics associated with different speech acts are relying on contextual, circumstantial, and interactional aspects, which do not rest on language alone. The perlocutionary force of a speech act is not a given value but is a dynamic process of socio-cognitive negotiation and discrimination.

3 Not to be confused with the distinction made by Jakobson (1971) between 'speech event' (as the actual situation of speaking, in which the participants find themselves) and 'narrated event' (as the state of affairs being talked about). Though this distinction might seem relevant in the investigation of authentic psychotherapeutic practice, the distinction is seldom, if ever, a clear-cut possibility.

4 In example, spatial markers regulate the distances between 'inner' and 'outer' events; temporal markers (therein verb tense) regulate the metaphorical distances of immediate and non-immediate events; selective order devices (therein syntax) regulate distances between concepts or shifts from agent status (active) to object status (passive)

5 As an example, a term like 'family' can both relate to a biological and social kinship as well as the 'family' as an institution, which has a social and cultural anchoring in history and is even kind of grounding the metaphoric use of 'family' as a caring system (as when gang members call each other 'brothers'). Yet 'family' can also relate to 'being a part' of a social system family, where becoming in the 'family' relies upon orienting to local sets of norms, value realizing activity and preferences (Hodges 2008). This might even point to an actual constellation of parents and children, which engage in actual dialogical endeavor. This way different non-local aspects of a social system 'family' can become attractors for conditioning the dialogical system. They are all connected across different timescales and thus there are interdependencies across the different 'levels' of abstraction. 
6 'A letter of concern' from an authoritative regarding a citizen, addressed to the municipality, can potentially be used against the citizen in lawsuit cases of parental authority and custody of children. Later in this session, it turns out, that this is exactly what the client fears are at stake.

7 Within therapeutic practice, the movement of body and gaze out of the dialogical responsive space is sometimes called a 'retreating to a reflective mind-space' - for either the client or the therapist " $(. .$.$) to explore inner thoughts and feel-$ ings"(Ladany et al, 2004). This 'retreating' and the reflective 'mind-space' can be explained with reference to what within cognitive psychology is referred to as an increase of the 'cognitive load' of a situation. Such a practice is not uncommon in therapy as in other settings build on high asymmetry of knowledge, i.e. interview practice, and often go on unnoticed. If not as in this example, actions like these are treated as flagging something unusual or potentially troublesome (Heldner \& Edlund, 2010).

8 A preferred response is a second part of an adjacency pair that consists of a sort of response to the first part that is not avoided by participants, in example, an expected answer in response to a question (Levinson 1983).

\section{References}

Alberdi, F., Rosenbaum, B, \& P. Sørensen (eds.). (2015). Moderne psykoterapi: Teorier og metoder, Hans Reitzels Forlag, København, 2015.

Antaki, C., Barnes, R. \& I. Leudar (2005). 'Diagnostic Formulations in Psychotherapy', Discourse Studies 7: 1-21.

Bakhtin, M.M. (1981). The Dialogic Imagination: Four Essays (C. Emerson and M. Holquist, Trans.) M. Holquist (Ed.). University of Texas Press, Austin.

Bang, J.C. \& J. Døør, (2007). Language, Ecology and Society - A Dialectical Approach (Ed. by S.V. Steffensen and J. Nash). Continuum, London.

Bartesaghi, M. (2009a). Conversation and Psychotherapy: How questioning reveals institutional answers, Discourse studies, vol. 11(2) p. 153-177.

Bartesaghi, M. (2009b). How the therapist does authority: Six strategies for substituting client accounts in the session, Communication \& Medicine, Vol.6(1) (2009), p. 15-25, DOI: 10.1558.cam.v5i2.15.

Bateman, A., \& Fonagy, P. (2010). Mentalization based treatment for borderline personality disorder. World Psychiatry, 9, 11-15. doi:10.1002/j.2051-5545.2010. tb00255.x.

Bateman, A., \& Fonagy, P. (2012). Handbook of mentalizing in mental health practice. London: American Psychiatric.

Benoit-Barné, C. \& Cooren, F. (2009). The Accomplishment of Authority Through Presentation: How Authority Is Distributed Among and Negotiated by Organizational Members, Management Communication Quarterly, Vol.23(1), p. 5-31, DOI: $10.1177 / 0893318909335414$.

Bercelli, F., Rossano, F. \& V. Maurizio (2013). Supra-session courses of action in psychotherapy, Journal of Pragmatics 57, p. 118-137.

Binnick, Robert, I. (1991). Time and the Verb: A Guide to Tense and Aspect, Oxford University Press. 
Borchmann, S. U. (2018). Utterances as tool-mediated specifications of affordances: Ecological pragmatics, In: Psychology of Language and Communication, Vol 22(1), p. 124-163.

Buchholtz, M. B., Spiekermann, J. \& H. Kächele (2015). Rhythm and blues - Amalie’s 152nd session: From psychoanalysis to conversation and metaphor analysis - and back again, The International Journal of Psychoanalysis, Vol 96(3), p. 877-910.

Buttny, R. (1996). Clients' and therapists' joint construction of clients' problems. Research on Language and Social Interaction 29: 125-143.

Clark, A. (2008). Supersizing the Mind: Embodiment, Action, and Cognitive Extension. Oxford: Oxford University Press.

Colombetti, G. \& J. Krueger (2015). Scaffoldings of the affective mind, Philosophical Psychology, Vol.28(8), p. 1157-1176, DOI: 10.1080/09515089.2014.976334.

Comrie, B. (1985). Tense, Cambridge, England: Cambridge University.

Comrie, B. [1989](1996). Language universals and linguistic typology. 5th edition. Chicago: University of Chicago.

Conte, C. (2009). Advanced Techniques for Counseling and Psychotherapy, Springer Publishing Company.

Cooren, F. (2010). Action and Agency in Dialogue Passion, incarnation and ventriloquism, John Benjamins Publishing, Amsterdam/Philadelphia, 2010.

Cornelius-White, J. H.D., Kanamori, Y., Murphy, D. \& E. Tickle. (2018). Mutuality in psychotherapy: A meta-analysis and meta-synthesis, Journal of Psychotherapy Integration, Vol 28(4), p. 489-504.

Crystal, David. (1985). A dictionary of linguistics and phonetics. 2nd edition. New York: Basil Blackwell.

Cuffari, E. C. \& Jensen, T. W. (2014). Living Bodies: Co-enacting Experience. In C. Müller, A. Cienki, E. Fricke, S. H. Ladewig, D. McNeill, \& J. Bressem. Handbook: Body - Language - Communication Vol 2 (pp. 2016-2025). Berlin: Mouton de Gruyter.

Eliasson, S. (2015). The birth of language ecology: interdisciplinary influences in Einar Haugen's "The ecology of language", Language Sciences, Volume 50, July 2015, Pages 78-92.

Enfield, N. P. (2014). Causal Frames for Understanding Language. In N. J. Enfield, P. Kockelman, \& J. Sidnell (Eds.), Cambridge Handbook for Linguistic Anthropology. Cambridge: Cambridge University Press.

Enfield, N.J. (2011). Sources of asymmetry in human interaction: enchrony, status, knowledge and agency, In: Stivers, Mondada, \& Steensig (eds.), The morality of knowledge in Conversation, Cambridge University Press, pp 285-312, https://doi. org/10.1017/CBO9780511921674.013.

Fleischman, S. (1989). Temporal Distance: A Basic Linguistic Metaphor, Studies in Language, Vol 13(1), p. 1-50, DOI: 10.1075/sl.13.1.02fle.

Flores-Ferrán, N. (2010). Letting go of the Past in Spanish Therapeutic Discourse: An Examination of Verbs and Discursive Variables, Pragmatics 20:1.43-70 (2010) International Pragmatics Association, DOI: 10.1075/prag.20.1.03flo.

Freud, S. (1916-17). Introductory lectures on psycho-analysis. Standard Edition 16 (pp. 243-463).

Froerer, A. S., \& Jordan, S. S. (2013). Identifying solution-building formulations through microanalysis. Journal of Systemic Therapies, 32(3), 60-73. 
García, E., \& Di Paolo, E. A. (2018). Embodied Coordination and Psychotherapeutic Outcome: Beyond Direct Mappings. Frontiers in psychology, 9, 1257. doi:10.3389/ fpsyg.2018.01257.

Goffman, E. (1959). The Presentation of Self in Everyday Life. New York: Doubleday.

Goffman, E. (1967). Interaction Ritual: Essays on Face-to-Face Behavior. New York: Doubleday.

Goodwin, C. (2003). The Body in Action, In: Coupland, J. \& Gwyn, R.(eds.). 2003. Discourse, the Body and Identity, New York, Palgrave Macmillan, pp. 19-42.

Goodwin, C. (2013). The co-operative, transformative organization of human action and knowledge. Journal of Pragmatics, 46(1), 8-23. Doi:10.1016/j. pragma.2012.09.003.

Grice, H. P. (1975). Logic and conversation, In: Cole, P. \& J. L. Morgan (eds). 1975. Syntax and semantics: Speech acts. Volume 3. New York: Academic. 9683101704, p. 41-58.

Guilfoyle, M. (2002). From Therapeutic Power to Resistance? Therapy and Cultural Hegemony, Theory \& Psychology, vol 15(1), p. 102-124.

Hansen, E., \& Heltoft, L. (2011). Grammatik over det Danske Sprog. (1 ed.) Det Danske Sprog- og Litteraturselskab.

Hak, T. and de Boer, F. (1996) 'Formulations in First Encounters', Journal of Pragmatics 25: 83-99.

Heritage, J., \& Clayman, S. E. (2010). Talk in action. Interactions, identities, and institutions. Chichester, UK: Wiley-Blackwell.

Jakobson, R. (1971). II. Word and Language, 1971, In: Jakobson R., Selected Writings (ed. Stephen Rudy). The Hague, Paris, Mouton, in six volumes (1971-1985).

Jordan, S. S., Froerer, A. S., \& Bavelas, J. B. (2013). Microanalysis of positive and negative content in solution-focused brief therapy and cognitive.

Järvilehto, T. (1998). The theory of the organism-environment system: I. Description of the theory. Integrative Physiological and Behavioral Science 33, 321-334.

Järvilehto, T. (2009). The theory of the organism-environment system as a basis of experimental work in psychology. Ecological Psychology, vol. 21(2), 112-120.

LeBaron, C. \& J. Streeck. (2000), Gesture, Knowledge, and the World, In: McNeill, D. (eds.), Language and gesture, Cambridge University Press.

Lepper, G. (2009) The pragmatics of therapeutic interaction: An empirical study, The International Journal of Psychoanalysis, 90:5, 1075-1094, DOI: 10.1111/j.17458315.2009.00191.x

Levinson, S. C. (1983). Pragmatics. Cambridge, England: Cambridge University.

Linell. P. \& T. Luckmann (1991). Asymmetries in dialogue: conceptual preliminaries, In: Markova, I. \& Foppa, K. (eds.). 1991. Asymmetry in dialogues, Hemel Hempstead, Harvester Wheatsheaf.

Linell, P. (2009). Rethinking Language, Mind, and World Dialogically: Interactional and Contextual Theories of Human Sense-making. Information Age Publishing, Charlotte, NC.

Love, N., (2004). Cognition and the language myth. Language Sciences 26 (6), 524544.

Love, N., (2007). Are languages digital codes? Language Sciences 29 (5), 690-709.

Markova, I. (2003). Dialogicality and social representations. Cambridge: Cambridge University Press, 2003. 
Maynard, D.W. (1991). 'Interaction and Asymmetry in Clinical Discourse', American Journal of Sociology 97: 448-95.

McGee, D. R. (1999). Constructive questions: How do therapeutic questions work? Unpublished doctoral dissertation, Department of Psychology, University of Victoria, Victoria, B. C., Canada.

McGee, D., Del Vento, A. \& Bavelas, B. J. (2005) `An Interactional Model of Questions as Therapeutic Interventions', Journal of Marital and Family Therapy 31(4): 371-84.

Menary, R. (2010). Introduction to the special issue on 4E cognition. Phenomenology and the Cognitive Sciences, 9(4), 459-463.

Mishler, E. (1986) Research Interviewing: Context and Narrative. Cambridge, MA: Harvard University Press.

Muntigl, P., Chubak, L. \& L. Angus. (2017). "Entering chair work in psychotherapy: An interactional structure for getting emotion-focused talk underway", Journal of Pragmatics, Elsevier BV, vol. 117, pp. 168-189, http://dx.doi.org/10.1016/j. pragma.2017.06.016.

Mörtl, K. \& Gelo O.C.G. (2015). Qualitative methods in psychotherapy process research. In: Gelo OCG, Pritz A, Rieken B (eds.), Psychotherapy research: foundations, process, and outcome. Springer, Heidelberg.

Noë, A. (2009). Out of our heads: Why you are not your brain, and other lessons from the biology of consciousness: Macmillan.

Peräkylä, A. 2011. After interpretation.: Third position utterances in psychoanalysis. Research on Language and Social Interaction, Vol 44(3), p. 288-316.

Peräkylä, A., Antaki, C., Vehviläinen, S., \& Leudar, I. (Eds.). 2008. Conversation analysis and psychotherapy. New York, NY, US: Cambridge University Press.

Ponsi, M. (2000). Therapeutic Alliance and Collaborative Interactions, The Interactional Journal of Psychoanalysis, Vol.20, p. 687-704.

Ribeiro A. P., Ribeiro, E., Loura, J., Gonçalves, M. M., Stiles, W. B., Horvath, A. O. \& I. Sousa. (2014). Therapeutic collaboration and resistance: describing the nature and quality of the therapeutic relationship within ambivalence events using the Therapeutic Collaboration Coding System, Psychotherapy Research, Vol.24(3), p.346-359. doi: 10.1080/10503307.2013.856042.

Sacks, H., Schegloff, E. A. \& G. Jefferson. (1974). "A simplest systematics for the organization of turn taking for conversation.” In: Schenkein, Jim (editor). 1978. Studies in the organization of conversational interaction. New York: Academic.

Safran, J.D., Muran, J.C. \& C. Eubanks-Carter (2011). Repairing alliance ruptures, Psychotherapy, Vol.48(1), p. 80-87. doi: 10.1037/a0022140.

Searle, J. (1969). Speech acts: An essay in the philosophy of language. Cambridge, England: Cambridge University.

Sidnell, Jack (ed.), (2009). Conversation Analysis: Comparative Perspectives, Cambridge, Cambridge University Press .

Smoliak, O. \& T. Strong, (eds.) (2018). Therapy as Discourse: Practice and Theory, Springer Verlag.

Steffensen, S.V. (2012). Care and conversing in dialogical systems. Language Sciences 34 (5), 513-531 (Special issue on Caring and conversing: The distributed dynamics of dialogue, ed. by. B.H. Hodges, S.V. Steffensen and J.E. Martin.). 
Steffensen, S. V. (2013). Human interactivity: Problem-solving, solution-probing and verbal patterns in the wild. In S. J. Cowley \& F. Vallée-Tourangeau (Eds.), Cognition Beyond the Brain: Computation, Interactivity and Human Artifice (pp. 195-221). Dordrecht: Springer.

Steffensen, S. V. \& Harvey, M. I. (2018). Ecological meaning, linguistic meaning, and interactivity. Cognitive Semiotics, 11(1).

Steffensen, S. V. \& Pedersen, S. B. (2014). Temporal Dynamics in Human Interaction. Cybernetics \& Human Knowing, 21(1-2), 80-97.

Steffensen, S.V. \& A. Fill. (2014). Ecolinguistics: the state of the art and future horizons, Language Sciences 41 (2014) 6-25.

Streeck, C. Goodwin \& C. LeBaron (eds.) (2011). Embodied Interaction: Language and Body in the Material World, Cambridge: Cambridge University Press. 67-78.

Streeck, Jürgen. (2010). Ecologies of gesture: Action and interaction. J Streeck (ed.). New Adventures in Language and Interaction. Amsterdam: John Benjamins. 221 240.

Taylor, L., \& Simon, J. (2014). Opportunities: Organizing the solution-focused interview. Journal of Systemic Therapies, 33(4), 62-78.

Thibault, P. (2011). First-Order Languaging Dynamics and Second-Order Language: The Distributed Language View, Ecological Psychology, Vol. 23(3), p. 210-245.

Tranekjær, L (2020) LEAN diversity management in practice: The multi-functionality of questions as a resource to ensure understanding, participation and procedural compliance in a diverse workplace. Scandinavian Studies in Language.

Trasmundi et al. (forthcoming). The Emergence and Management of Embodied, Ethical Dilemmas in Psychotherapy: A Qualitative Study, to appear in: Voutilainen, L., Peräkylä, A. \& J. Ruusuuori (2011). Therapeutic change in interaction: conversation analysis of a transforming sequence, Psychotherapy Research, Vol 21(3), p. 348-365. doi: 10.1080/10503307.2011.573509.

Yao, X. \& W. Ma. (2017). Question resistance and its management in Chinese psychotherapy, Discourse Studies, vol. 19, 2: pp. 216-233. 